This PDF is a selection from an out-of-print volume from the National Bureau of Economic Research

Volume Title: Taxation in the Global Economy

Volume Author/Editor: Assaf Razin and Joel Slemrod, editors

Volume Publisher: University of Chicago Press

Volume ISBN: 0-226-70591-9

Volume URL: http://www.nber.org/books/razi90-1

Conference Date: February 23-25, 1989

Publication Date: January 1990

Chapter Title: Tax Incentives and International Capital Flows: The Case of the United States and Japan

Chapter Author: Lans Bovenberg, Krister Anderson, Kenji Aramaki, Sheetal K. Chand

Chapter URL: http://www.nber.org/chapters/c7212

Chapter pages in book: (p. $283-328$ ) 


\title{
8 \\ Tax Incentives and International Capital Flows: The Case of the United States and Japan
}

\author{
A. Lans Bovenberg, Krister Andersson, Kenji Aramaki, \\ and Sheetal K. Chand
}

The internationalization of financial markets has contributed to the growing interdependence of the world's economies. In particular, policy or other shocks that affect domestic savings-investment balances may set in motion large international capital flows. Accordingly, policymakers increasingly recognize that their macroeconomic policies may have important international ramifications.

Tax rules, especially those regarding the taxation of capital income, potentially have powerful effects on savings-investment balances and, therefore, on external current accounts and international capital flows. Moreover, the integration of financial markets has made tax rules more powerful in affecting the global allocation of investment and savings, thereby potentially distorting the worldwide allocation of resources. Thus, with the capital markets of the major industrial countries now much more integrated, changes in the structure of capital income taxes in one country can have major implications for other countries by affecting international capital flows and global efficiency. This raises important issues of surveillance and coordination in an international context (see Tanzi and Bovenberg 1988). Nevertheless, with only a few recent exceptions (see Alworth and Fritz 1988; Fukao and Hanazaki 1987; Sinn 1987; Tanzi 1988; Sorenson 1987; and Boadway, Bruce, and Mintz 1984, 1987), the

A. Lans Bovenberg is an economist in the Fiscal Affairs Department of the International Monetary Fund. Krister Andersson is an economist in the Western Hemisphere Department of the International Monetary Fund. Kenji Aramaki is deputy director, Office of Investment Trust and Management, Securities Bureau, Ministry of Finance, Tokyo, Japan. Sheetal K. Chand is an advisor in the Fiscal Affairs Department of the International Monetary Fund.

Comments received from Vito Tanzi, Ved Gandhi, George Kopits, Liam Ebrill, Owen Evans, Roger Smith, and other colleagues, together with those from participants of a seminar at the NBER Summer Institute, are greatly appreciated. The authors wish to thank Eric Sidgwick for invaluable research assistance. The opinions expressed in this paper are those of the authors and do not necessarily represent the views of the International Monetary Fund or its staff. 
international implications of domestic tax rules have received relatively little attention.

This study explores how tax incentives for investment and savings affect international capital flows as well as national and global welfare. It measures the incentive effects of capital income taxation by using the concept of the tax wedge, which has been developed in the academic literature (see, e.g., King and Fullerton 1984; Auerbach 1983; and Boadway 1985). Most studies using this concept have applied it only to investments financed domestically. A major purpose of this study is to extend the methodology to analyze cross-border investments. This paper also presents some results on how the tax systems in Japan and the United States have interacted over the period 1980-87 in a manner that could affect bilateral capital flows and the efficiency with which resources are allocated between them.

The plan of the paper is as follows. Section 8.1 discusses the scope of the study. Section 8.2 introduces the concept of the tax wedge and describes how it can be used to measure the incentive effects of capital income taxation, both in closed and in open economies. Section 8.3 develops a methodology for summarizing the effects of capital income taxation on international capital flows and welfare. Section 8.4 presents the information on tax parameters and the economic environment needed for the application of the methodology to Japan and the United States and briefly discusses the major tax reforms in recent years in the two countries. Section 8.5 applies the methodology to Japanese and U.S. data for the years 1980, 1984, and 1987, in order to highlight the major tax reforms, and interprets the results. Finally, the concluding section relates the results to the observed movements in savings and investment balances in Japan and the United States and briefly examines the case for coordinating tax policy internationally.

\subsection{The Scope of the Study}

This study focuses on portfolio rather than direct investment for two reasons. First, portfolio investment can be expected to be more sensitive to after-tax rates of return than direct investment; the latter investments are undertaken for reasons other than temporary higher rates of return, such as avoiding protectionist barriers or entering a market. Second, the share of portfolio investment in private capital flows has increased in recent years, in particular, during the 1980s. Tables 8.1 and 8.2 show the composition of private capital flows from and to the United States during the period 1980-87. In Japan, developments in long-term capital flows are almost entirely determined by movements in portfolio investment (fig. 8.1).

This study does not explicitly consider the role of intermediaries, although tables 8.1-8.3 reveal their importance. Japanese savers in particular show a marked preference for saving through intermediaries (table 8.3). Nevertheless, some of the study's results will continue to hold, even if funds are 


\begin{tabular}{|c|c|c|c|c|c|c|c|c|}
\hline & 1980 & 1981 & 1982 & 1983 & 1984 & 1985 & 1986 & 1987 \\
\hline U.S. private investment aboard ${ }^{a}$ & 83,382 & 104,516 & 95,304 & 44,265 & 15,643 & 43,203 & 113,891 & 100,234 \\
\hline Direct investments abroad & 27,517 & 12,973 & $-20,596$ & -549 & 4,277 & 18,770 & 29,312 & 49,318 \\
\hline Foreign securities & 5,853 & 720 & 12,100 & 8,353 & 5,301 & 23,706 & 20,385 & 13,530 \\
\hline Bonds & 1,521 & 2,330 & 10,890 & 972 & 4,134 & 11,181 & 8,782 & 9,240 \\
\hline Corporate stocks & 4,332 & $-1,610$ & 1,210 & 7,281 & 1,167 & 12,525 & 11,603 & 4,290 \\
\hline \multicolumn{9}{|l|}{ U.S. claims on unaffiliated foreigners reported by } \\
\hline U.S. nonbanking concems & 3,175 & 1,181 & $-7,270$ & 6,534 & $-5,061$ & $-1,005$ & 4,219 & $-3,145$ \\
\hline U.S. claims reported by U.S. banks, not included elsewhere & 46,794 & 89,622 & 111,070 & 29,927 & 11,126 & 1,732 & 59,975 & 40,530 \\
\hline Foreign private investment in the United States ${ }^{b}$ & 68,514 & 73,503 & 100,672 & 91,042 & 103,268 & 165,106 & 240,564 & 153,985 \\
\hline Direct investments in the United States & 28,584 & 25,668 & 15,963 & 12,384 & 27,522 & 20,032 & 35,799 & 41,513 \\
\hline U.S. securities & 17,430 & 3,363 & 25,156 & 28,911 & 37,810 & 104,322 & 110,482 & 22,482 \\
\hline Bonds & 1,179 & 3,541 & 13,268 & 8,833 & 39,619 & 75,196 & 67,503 & 15,761 \\
\hline U.S. Treasury securities & 1,903 & 2,392 & 7,253 & 8,088 & 24,349 & 25,441 & 7,862 & $-13,108$ \\
\hline Corporate and other bonds & -724 & 1,149 & 6,015 & 745 & 15,270 & 49,755 & 59,641 & 28,869 \\
\hline Corporate stocks & 16,251 & -178 & 11,888 & 20,078 & $-1,809$ & 29,126 & 42,979 & 6,721 \\
\hline \multicolumn{9}{|l|}{ U.S. liabilities to unaffiliated foreigners reported by } \\
\hline U.S. nonbanking concerns & 11,757 & 180 & $-3,074$ & -595 & 4,087 & $-1,566$ & $-2,833$ & 2,212 \\
\hline U.S. liabilities reported by U.S. banks, not included elsewhere & 10,743 & 44,292 & 62,627 & 50,342 & 33,849 & 42,318 & 97,116 & 87,778 \\
\hline
\end{tabular}

Source: U.S. Department of Commerce, Survey of Current Business.

${ }^{a}$ Changes (including valuation changes) in the year-end balance of U.S. private assets abroad.

${ }^{b}$ Changes (including valuation changes) in the year-end balance of foreign nonofficial assets in the United States. 


\begin{tabular}{|c|c|c|c|c|c|c|c|c|c|}
\hline & 1980 & 1981 & 1982 & 1983 & 1984 & 1985 & 1986 & 1987 & $\begin{array}{c}1980-87 \\
\text { Average }\end{array}$ \\
\hline U.S. private investment abroad ${ }^{\mathrm{a}}$ & 100.0 & 100.0 & 100.0 & 100.0 & 100.0 & 100.0 & 100.0 & 100.0 & 100.0 \\
\hline Direct investments abroad & 33.0 & 12.4 & -21.6 & -1.2 & 27.3 & 43.4 & 25.7 & 49.2 & 21.0 \\
\hline Foreign securities & 7.0 & .7 & 12.7 & 18.9 & 33.9 & 54.9 & 17.9 & 13.5 & 19.9 \\
\hline Bonds & 1.8 & 2.2 & 11.4 & 2.2 & 26.4 & 25.9 & 7.7 & 9.2 & 10.9 \\
\hline Corporate stocks & 5.2 & -1.5 & 1.3 & 16.7 & 7.5 & 29.0 & 10.2 & 4.3 & 9.1 \\
\hline \multicolumn{10}{|l|}{ U.S. claims on unaffiliated foreigners reported by } \\
\hline U.S. nonbanking concerns & 3.8 & 1.1 & -7.6 & 14.8 & -32.4 & -2.3 & 3.7 & -3.1 & -2.8 \\
\hline U.S. claims reported by U.S. banks, not included elsewhere & 56.1 & 85.7 & 116.5 & 67.6 & 71.1 & 4.0 & 52.7 & 40.4 & 61.8 \\
\hline Foreign private investment in the United States ${ }^{b}$ & 100.0 & 100.0 & 100.0 & 100.0 & 100.0 & 100.0 & 100.0 & 100.0 & 100.0 \\
\hline Direct investments in the United States & 41.7 & 34.9 & 15.9 & 13.6 & 26.7 & 12.1 & 14.9 & 27.0 & 23.3 \\
\hline U.S. securities & 25.4 & 4.6 & 25.0 & 31.8 & 36.6 & 63.2 & 45.9 & 14.6 & 30.9 \\
\hline Bonds & 1.7 & 4.8 & 13.2 & 9.7 & 38.4 & 45.5 & 28.1 & 10.2 & 19.0 \\
\hline U.S. Treasury securities & 2.8 & 3.3 & 7.2 & 8.9 & 23.6 & 15.4 & 3.3 & -8.3 & 7.0 \\
\hline Corporate and other bonds & -1.1 & 1.6 & 6.0 & .8 & 14.8 & 30.1 & 24.8 & 18.7 & 12.0 \\
\hline Corporate stocks & 23.7 & -.2 & 11.8 & 22.1 & -1.8 & 17.6 & 17.9 & 4.4 & 11.9 \\
\hline \multicolumn{10}{|l|}{ U.S. liabilities to unaffiliated foreigners reported by } \\
\hline U.S. nonbanking concerns & 17.2 & .2 & -3.1 & -.7 & 4.0 & -.9 & -1.2 & 1.4 & 2.1 \\
\hline U.S. liabilities reported by U.S. banks, not included elsewhere & 15.7 & 60.3 & 62.2 & 55.3 & 32.8 & 25.6 & 40.4 & 57.0 & 43.7 \\
\hline
\end{tabular}

Source: U.S. Department of Commerce, Survey of Current Business.

a Changes (including valuation changes) in the year-end balance of U.S. private assets abroad.

${ }^{b}$ Changes (including valuation changes) in the year-end balance of foreign nonofficial assets in the United States. 


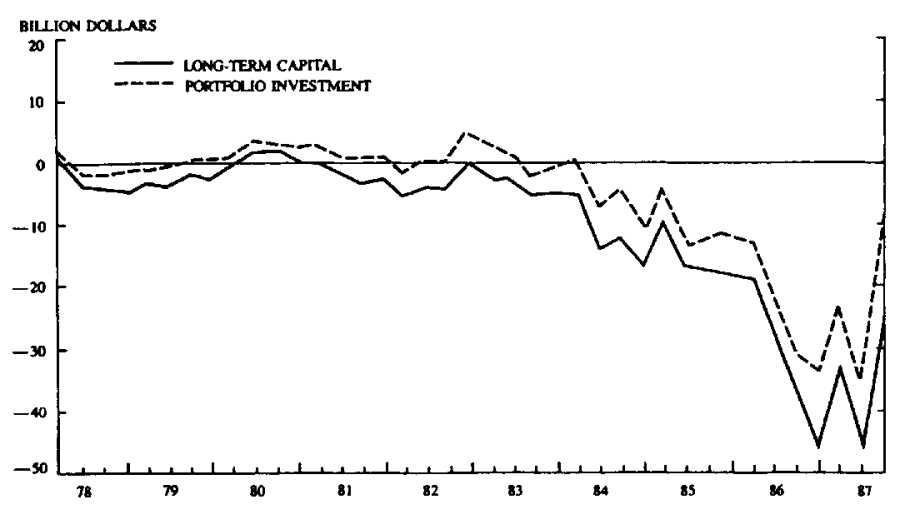

Fig. 8.1 Japan: Long-term capital and portfolio investment (shows changes in the long-term capital balance and in the portfolio investment balance) Source: Fukao and Okima (1988).

Table 8.3 Financial Assets of Households (\%)

\begin{tabular}{lcc}
\hline & Japan 1984 & United States 1983 \\
\hline Currency and sight deposit & 11.0 & 5.8 \\
Time deposit & 59.7 & 31.7 \\
Insurance and pension & 15.7 & 25.5 \\
Securities (stocks and bonds) & 13.1 & 35.1 \\
(Stocks) & $(1.5)$ & $(22.6)$ \\
$\quad$ Total & 100 & 100 \\
\hline
\end{tabular}

Source: Tachibanaki $(1988,23)$.

channeled through intermediaries, if these institutions are competitive, earning no monopoly profits at the margin. An explicit analysis of the role of intermediaries would require a separate study.

This study examines corporate investments that relate to machinery. Because tax treatments of investments in structures or noncorporate residential assets, especially housing, differ from those of corporate investments in machinery, some modification would be necessary to apply the formulas developed in the study to these investments.

Finally, table 8.1 reveals that part of portfolio investments were in government securities. Although we do not explicitly consider investments in government securities, our calculations can be readily used to infer the effect of taxes on after-tax rates of return to savers, as indicated in section 8.6.1

\subsection{Capital Income Taxation in Closed and Open Economies}

After introducing the concept of the tax wedge, this section analyzes how capital income taxes influence capital accumulation and welfare in a closed economy. It then turns to an open economy that is integrated in world 
financial markets. While the initial discussion considers the small open economy, which is conceptually the easiest to handle, the methodology of the paper is developed for the larger open economy, whose policies may influence world market conditions.

\subsubsection{The Tax Wedge Concept}

An investment project involves a saver sacrificing consumption today by transferring resources to the project. At some point in the future, the saver earns a return on the investment. If taxes are absent, the saver's return coincides with the rate of return earned on the investment. Capital income taxes, however, constitute a wedge between the pretax return on investment and the after-tax return on savings.

The concept of the tax wedge can be explained ${ }^{1}$ by defining three rates of return: the required before-tax return on investment $p$, the market return $r$, and the after-tax return on savings $s$. All these returns are measured in real terms.

The market return $r$ represents the price of funds on capital markets and provides the link between the firm carrying out the investment and the saver providing the financing. It is the return that the firm pays to the saver after it has paid corporate tax but before the saver has met personal tax liabilities. The funds may be in the form of either debt or equity. In the case of debt finance, the market return corresponds to the real interest rate. For equity financing, it amounts to the real return on equity (including retained earnings) before personal taxes.

The minimum rate of return that the firm must earn before taxes in order to be able to pay any taxes due and a market rate of return $r$ is denoted by $p$. This required before-tax rate of return is the conventional user cost of capital measured net of depreciation. The relation between $p$ and $r$ depends both on macroeconomic variables, such as the inflation rate, and on tax provisions, for example, regarding depreciation allowances, investment grants, and the deductibility of interest expenses. The cost of capital function, which links $p$ to $\mathrm{r}$, summarizes these various factors:

$$
c(r)=p .
$$

The cost of capital function generally depends on the type of asset and industry as well as on the form of financing because the tax system typically discriminates between different assets, industries, and types of financing.

The after-tax return function formalizes the relation between the market rate and the after-tax return received by the saver:

$$
d(r)=s .
$$

This relation is typically affected by the inflation rate and the personal tax treatment of the saver. Furthermore, it generally depends on whether the 
saver provides funds directly or through an intermediary, such as a bank, pension fund, or life insurance company, and on whether the funds are in the form of debt or equity.

The total tax wedge $t$ is defined as the difference between the required pretax rate of return and the posttax return received by the saver:

$$
t=p-s \text {. }
$$

One can interpret the tax wedge as the equivalent of a wealth tax rate because it is the difference between two rates of return on an asset. ${ }^{2}$

\subsubsection{The Closed Economy}

The extensive literature on the effects of capital income taxation in a closed economy summarizes the disincentive effects of capital income taxation by the total tax wedge $t$. King and Fullerton (1984), for example, calculated these tax wedges for eighty-one different hypothetical investment projects in each of the following four countries: the United States, the United Kingdom, the Federal Republic of Germany, and Sweden. The eighty-one projects combine three types of assets (machinery, buildings, and inventories), three types of industries (manufacturing, commerce, and other), three types of financing (debt, retained earnings, and new share issues), and three types of owners (households, tax-exempt institutions, and insurance companies). The study did not consider international capital flows. Accordingly, firms are assumed to finance their investments by raising funds from savers who reside domestically.

\section{Savings and Investment}

Figure 8.2 illustrates how the total tax wedge $t$ affects the capital market equilibrium in a closed economy setting. The investment schedule relates the flow of investment to $p$. According to the neoclassical theory of investment behavior, which we shall assurne here, firms carry out investments until the

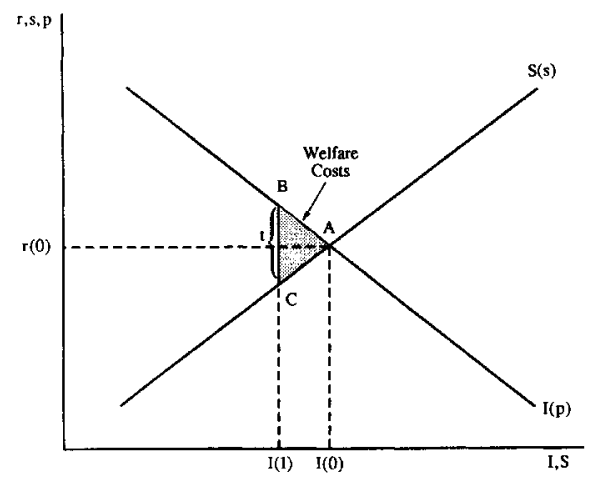

Fig. 8.2 Tax wedge and welfare costs: the closed economy case 
before-tax return (i.e., the internal rate of return) equals the required rate of return $p$. Accordingly, in the absence of externalities, the investment schedule represents the marginal product of investment at different levels of investment. Its downward slope reflects diminishing marginal returns on investment. ${ }^{3}$ The slope of the investment curve is inversely related to the elasticity of investment with respect to the required return $p$.

The savings schedule relates the flow of savings to the after-tax return $s$. The upward slope of the savings schedule reflects a positive compensated savings elasticity. The smaller the slope is, the larger the savings elasticity becomes.

If taxes are absent and intermediation costs are ignored, both the beforeand after-tax returns coincide with the market return:

$$
r=s=p,
$$

and equilibrium in figure 8.2 is found at the point $A$ where the savings and investment schedules intersect.

Taxes drive a wedge between the before- and the after-tax returns. Given the investment and savings elasticities, the total tax wedge $t$ contains enough information to find the effects of capital income taxes on savings and investment. To illustrate, in figure 8.2 the tax wedge is given by the distance $B C$. Thus, in this particular case, the wedge is positive, and the required before-tax return on investment exceeds the after-tax return received by the saver. ${ }^{4}$ This positive wedge reduces both investment and savings by the distance $I(0) I(1)$. The more elastic savings and investment are, the flatter the curves become, and the more powerful a given tax wedge is in affecting savings and investment.

\section{Welfare}

Once the effects of the tax wedge on savings and investment are determined, the welfare effects in a closed economy can more easily be determined. On the savings side, households are assumed to equate the after-tax return on their marginal savings $s$ to the opportunity cost of delaying consumption, which measures the social costs of financing the investment. ${ }^{5}$ On the investment side, firms equate the required return $p$ to the before-tax return on marginal investment. This latter return includes both the return received by savers and the tax revenues collected by the government. Accordingly, in the absence of externalities, $p$ measures the social benefits that a marginal investment earns for society as a whole. ${ }^{6}$ The total tax wedge, therefore, captures the difference between the social benefits $p$ and the social costs $s$ associated with a marginal investment. In figure 8.2, the tax wedge reduces capital accumulation by $I(0) I(1)$. The social benefits of these crowded-out units, as measured by the before-tax return $p$, exceed their social costs, as measured by the after-tax return $s$. Accordingly, the tax wedge reduces welfare by the triangle $A B C$. If investment and savings 
become more sensitive to rates of return, a given tax wedge implies larger welfare losses.

The total tax wedge in the closed economy must be divided into two parts in order to find the effect of capital income taxes on the market return $r$. The first part is the corporate tax wedge $t_{c}$ between the before-tax and market returns:

$$
t_{c}=p-r .
$$

The second wedge, which is called the personal tax wedge $t_{p}$, measures the effect of personal taxes and amounts to the gap between the market return and the after-tax return received by the saver:

$$
t_{p}=r-s
$$

In a closed economy, if the size of the total tax wedge is kept unchanged, the personal-corporate split affects neither capital accumulation nor welfare. In these circumstances, the composition of the tax wedge affects only the market return. If the personal tax wedge is reduced to zero and the corporate tax wedge is increased so as to account for the whole predetermined wedge between $p$ and $s$, there would be pressure on investment to decline. Thus, the market rate would be reduced, while savings would be stimulated, further reducing the market rate. It can be readily demonstrated that the market rate would decline by just the amount needed to offset the effects of the changing tax factors on the after-tax return to savings and the costs of investment. It is only by changing the size of the total tax wedge that savings and investment are modified. If the share of the personal tax wedge in the total tax wedge becomes larger, the market rate falls less. The market return rises if the share of the personal tax wedge in the total tax wedge becomes large enough.

\subsubsection{The Open Economy}

\section{Savings, Investment, and Capital Flows}

In an open economy, domestic savings and domestic investment do not necessarily balance because of the possibility of nonzero net capital flows with the rest of the world. The existence of international capital markets has important implications for the analysis of capital income taxation. In particular, it becomes important to distinguish between savings and investment incentives and to attend to the composition of the tax wedge.

Figure 8.3 illustrates the differential effects of savings and investment incentives in the case of a small open economy in which international capital markets fix the domestic market return at the rate of return on world capital markets $r^{*} .{ }^{7}$ If taxes are absent, both the before-tax return on investment and the after-tax return on savings equal the return on world markets:

$$
p=s=r^{*} \text {. }
$$




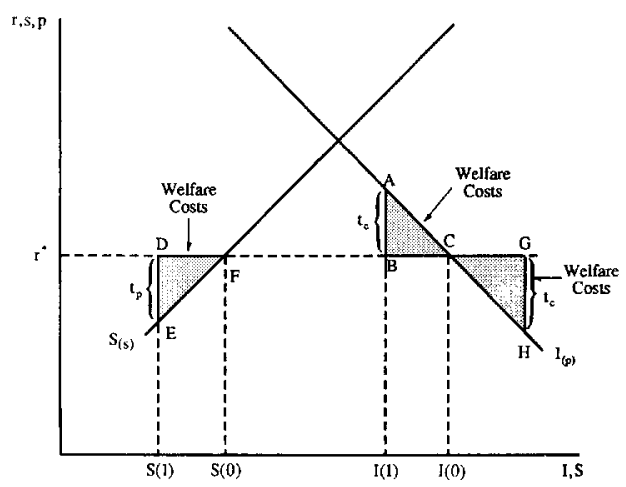

Fig. 8.3 Tax wedge and welfare costs: the small open economy case

In the case depicted in figure 8.3 , investment exceeds savings by the distance $I(0) S(0)$ if domestic returns equal the world rate of return. Accordingly, the economy runs a current account deficit of that magnitude. ${ }^{8}$

The introduction of capital income taxes affects investment, savings, and capital flows. Unlike in the closed economy, where the total wedge affects both savings and investment, in the small open economy the corporate tax component of the wedge affects only investment, while the personal tax component affects only savings.

In figure 8.3 , a corporate tax wedge of the size $A B$ reduces investment by the distance $I(0) I(1)$ but fails to affect domestic savings. Accordingly, the current account deficit falls by $I(0) I(1)$. It is of interest that the infinitely elastic supply of world savings implicit in the fixed market return $r^{*}$ makes the corporate tax wedge more powerful in affecting domestic investment than in a closed economy. This is because the market rate would decline in a closed economy, which would cushion the effect of raising the corporate tax component.

The personal tax wedge does not affect domestic investment but reduces domestic savings and, therefore, weakens the external current account. In figure 8.3, for example, a personal tax wedge of the magnitude $D E$ widens the current account deficit by the distance $S(0) S(1)$. As with the effect of corporate taxes on investment, the more open the economy, the more powerful the effects of the personal tax wedge on domestic savings.

\section{National Welfare Effects}

The openness of the economy also has important consequences for the effects of capital income taxation on national welfare. In the small open economy in figure 8.3 , the rate of return on world markets $r^{*}$ corresponds to the national cost of financing a marginal investment. ${ }^{9}$ The required before-tax rate of return measures the national benefits associated with a marginal investment (see subsec. 8.2.2). Accordingly, the corporate tax 
wedge, which is the difference between the before-tax and the market returns, measures the gap between the national benefits and the national costs associated with marginal investment. In figure 8.3 , the corporate tax wedge $A B$ reduces national welfare by the triangle $A B C$ because this tax wedge crowds out the investment units $I(0) I(1)$ for which national benefits exceed national costs. A given corporate tax wedge imposes larger national welfare losses in an open economy than it does in a closed economy owing to its greater effect on investment.

The personal tax wedge corresponds to the gap between the national benefits and costs associated with a marginal unit of domestic savings. In figure 8.3 , a personal tax wedge of the size $D E$ reduces national welfare by the triangle $D E F$. In a closed economy, a subsidy at the corporate level could have mitigated the welfare losses. In particular, a negative corporate tax wedge equal in absolute value to the personal tax wedge would have avoided the welfare losses altogether. In an open economy, in contrast, such an investment subsidy only adds welfare costs at the investment side to those imposed by the savings tax. For example, in figure 8.3 , the investment subsidy implicit in the negative corporate tax wedge $-G H=-D E$ adds welfare losses amounting to the triangle $C G H$ to the welfare costs corresponding to the area $D E F$ imposed by the taxation of savings. ${ }^{10}$

\section{World Welfare Effects}

This subsection examines how international differences in investment incentives affect global efficiency. Instead of a small open economy, we now consider a hypothetical world or closed economy consisting of only the United States and Japan. In figure 8.4, the distance between the two vertical

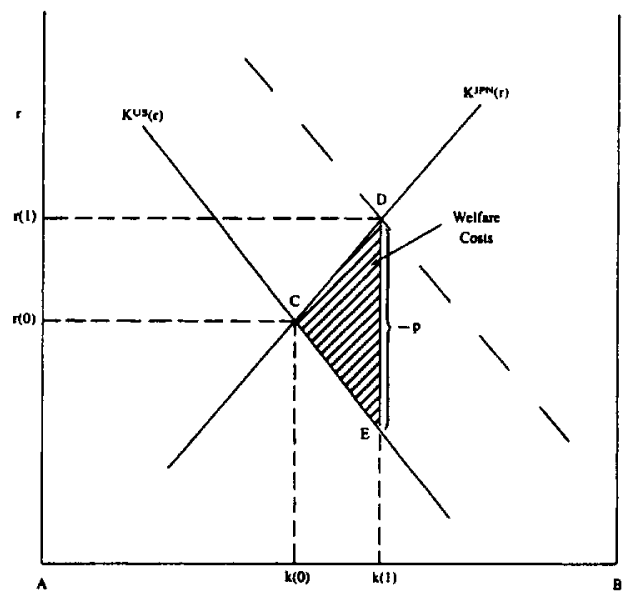

Fig. 8.4 Corporate tax wedges and the international allocation of the capital stock 
axes measures the size of the world capital stock, which is assumed to be fixed so as to focus on the international allocation of capital. ${ }^{11}$ The solid downward and upward sloping lines represent the marginal product curves in, respectively, the United States and Japan. The schedule for the United States is measured from the left axis and that in Japan from the right axis. If taxes and externalities are absent, these curves coincide with the capital demand curves as a function of the cost of funds. In that case, the intersection of the two solid lines $C$ represents the equilibrium in world capital markets. At this nontax equilibrium, the return on world markets amounts to $r(0)$ while a part $A K(0)$ of the world capital stock is located in the United States.

If the United States provides an investment incentive corresponding to a negative corporate tax wedge equal in absolute value to $-p=D E$, the capital demand curve in the United States shifts upward to the dotted line. As a consequence, the return on world markets rises to $r(1)$ and a part of the world capital stock corresponding to $K(1) K(0)$ gradually moves from Japan to the United States. During the transition to this new long-run equilibrium, net investment in the United States rises relative to that in Japan, and the external current account of the United States weakens.

Conceptually, differential investment incentives distort the global playing field and, if externalities are absent, harm global welfare. With differential investment incentives, equal after-tax returns on assets located in different countries correspond to different before-tax returns on those assets. This violates a necessary condition for efficiency in the allocation of capital, namely, that before-tax returns on different assets should be equal. Overall welfare could be raised by relocating capital from countries with a lower before-tax return to those with higher returns. For example, in figure 8.4 , the differential investment incentive corresponding to $D E$ reduces world welfare by the triangle $D C E$ because the capital $K(0) K(1)$ earns a lower before-tax return in the United States than it could earn in Japan.

\subsection{Methodology}

In this section, the tax wedge concept is extended to cross-border portfolio investments by allowing foreign residents to finance domestic investments and domestic residents to finance foreign investments. In particular, tax wedges are computed for all host-residence (or saver-investment) combinations. A residence country is characterized by a typical saver, while a typical investment represents the host country. Regarding the financing instruments, the study distinguishes between debt and equity finance. New share issues and retained earnings are assumed to account for fixed proportions of total equity financing.

The study disaggregates the total tax wedge for each host-residence combination into three separate wedges corresponding to, respectively, corporate taxes $\left(t_{c}\right)$, withholding taxes $\left(t_{w}\right)$, and residence taxes $\left(t_{r}\right)$ (fig. 8.5). The withholding and residence wedges add up to the personal tax 
host B

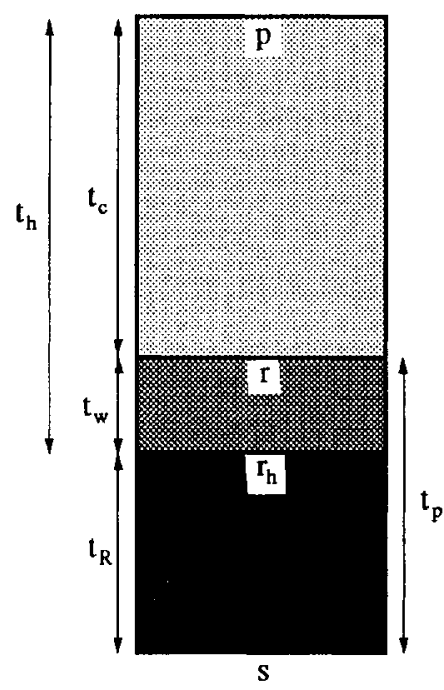

Residence A

Figure 8.5 Tax wedge components

wedge $\left(t_{p}\right)$. Subsection 8.3.1 discusses the measurement of the corporate tax wedge. Subsection 8.3.2 defines international differences in investment incentives and explores how differential corporate tax wedges relate to these differences. It shows that the residence principle cannot be assumed, therefore precluding the easier route considered in the preceding section whereby investment incentives would be identified with corporate tax wedges. The effects of investment incentives on international capital flows and global efficiency are analyzed in subsection 8.3.3. Subsection 8.3.4 defines international differences in savings incentives, and subsection 8.3.5 then explores the corresponding effects of savings incentives. Subsection 8.3.6 defines the host tax wedge $\left(t_{h}\right)$ as the sum of the corporate and withholding tax wedges and explores how the host-residence split affects national welfare. The appendix contains the mathematical expressions for the tax wedges and their components for, respectively, debt- and equity-financed investments.

\subsubsection{Corporate Tax Wedges}

To compute the corporate tax wedge, two assumptions are made. First, only the host country collects corporate taxes. Second, corporate taxes do not discriminate between domestic and foreign savers. Accordingly, the corporate tax rate on a given investment is the same irrespective of whether the saver financing the investment is residing abroad or domestically. 
The two assumptions are generally met for portfolio investments. Even in the case of direct investments, the host country tax system may determine the effective corporate tax wedge on marginal investments. This is the case, for example, if the residence country has a territorial system of corporate taxation or if firms are in an overall excess credit position under a system of worldwide taxation. ${ }^{12}$ Moreover, residence countries typically tax income from subsidiaries only on repatriation, unless it is earned in a tax haven. Under these circumstances, host taxes determine marginal investment incentives if firms, at the margin, finance foreign investment by retained earnings, which appears to be a dominant form of marginal financing (see Hartman 1985; and Sinn 1987).

\subsubsection{The Measurement of Investment Incentives}

Section 8.2 used the corporate tax wedge to measure the effect of capital income taxation on investment incentives in a small open economy. This procedure, which greatly simplifies the analysis, is valid only if international capital markets equalize market returns across different jurisdictions. This, in turn, requires two assumptions. First, assets located in different countries should be perfect substitutes in demand so that savers residing in a given country require the same after-tax return $s$ on all their assets. Second, personal taxes should be collected on the basis of the residence principle. According to this principle, residence governments tax real capital income (after corporate tax) at a personal tax rate that does not depend on the country where the capital income originates. Only if this principle holds does the equalization of after-tax returns by savers correspond to the same market returns (fig. 8.6).

In practice, the residence principle may fail to hold for at least three reasons. ${ }^{13}$ First, even if residence countries apply the residence principle to nominal returns, real returns are likely to be taxed differently if inflation rates diverge between host countries. In particular, financial instruments denominated in the currency of low-inflation countries tend to benefit from a preferential tax treatment of capital gains because these securities earn a large part of their returns in the form of an exchange rate appreciation (i.e., capital gains), which are typically taxed at lower rates (see, e.g., Gordon 1986; and Sorenson 1986).

Second, withholding taxes on income earned by nonresidents violate the residence principle if savers do not have sufficient residence liabilities against which to credit the foreign withholding taxes. This may be the case if they save through tax-exempt institutions. ${ }^{14}$

A third reason why the residence principle may fail concerns the integration of corporate and personal taxation. Under the numerous methods of integration, residence countries typically impose different tax rates at the personal level depending on whether corporate tax has been levied domestically or abroad (see Sato and Bird 1975). Moreover, host countries may allow corporate credits only if dividends are paid to residents. 
host $\mathrm{A}$ host $\mathrm{B}$

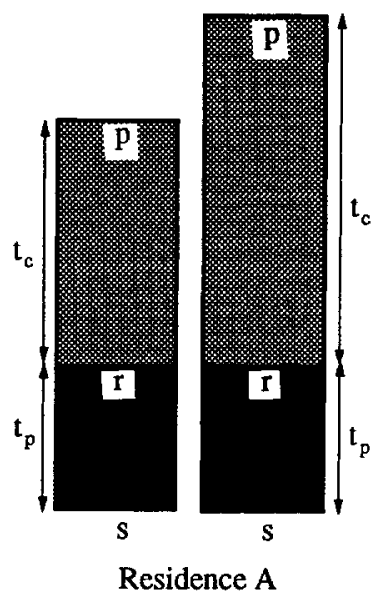

Figure 8.6 The residence principle

For these reasons, the residence principle, although it would have simplified the analysis, will not be adopted here. As a consequence, differences in investment incentives cannot be measured simply as differences in corporate tax wedges. Instead, the incentives are measured by comparing, for a given saver, the total tax wedges on investments located in different host countries, as illustrated in figure 8.7.

Investment incentives may differ for savers residing in different countries if the residence principle does not hold. In that case, the tax systems provide incentives for tax arbitrage between savers residing in different countries. However, savers do not fully exploit these arbitrage opportunities because assets located in different countries-although easily substitutable-are assumed not to be perfect substitutes in demand. ${ }^{15}$

\subsubsection{The Effect of Investment Incentives on International Capital Flows and Global Efficiency}

The measure of investment incentives developed here summarizes how personal and corporate income taxes interact to affect international capital flows. If, for example, tax wedges on assets located in country A exceed those on assets in country $B$, and if all other conditions are equal, the tax system provides incentives for capital flows from $\mathrm{A}$ to $\mathrm{B}{ }^{16}$

Such differences indicate how the interaction of capital income taxes in various countries distorts the international allocation of capital by violating 


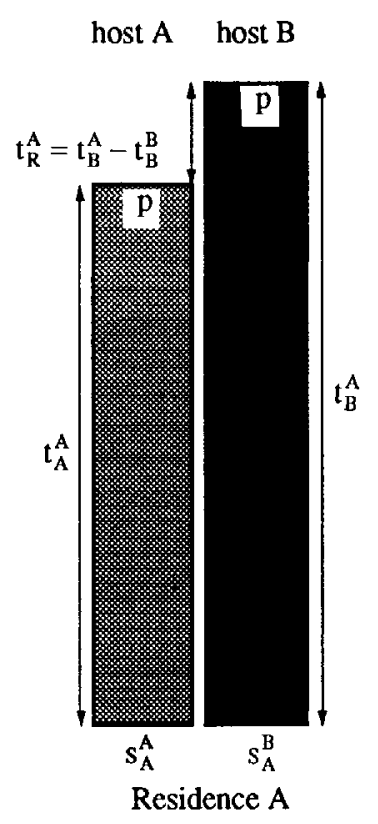

Figure 8.7 The measurement of investment incentives

what may be stated as the principle of capital export neutrality. According to this principle, savers should face the same tax rate on assets located in different countries (in the absence of externalities) so that tax systems do not interfere with an efficient global allocation of capital. The principle requires that investors be indifferent between assets located in different countries on both a before-tax and an after-tax basis. If the intercountry tax wedges differ, equal after-tax returns will fail to yield the equal before-tax returns that are required for an efficient allocation of capital. Figure 8.7 illustrates that a higher tax wedge on assets in B compared with that in A causes the before-tax return in B to rise above that in A. Accordingly, in the absence of externalities, moving capital from $\mathrm{A}$ to $\mathrm{B}$ would raise overall welfare.

\subsubsection{The Measurement of Savings Incentives}

International differences in saving incentives are measured by comparing, for a given asset, the total tax wedges on savers residing in different countries (fig. 8.8). In this paper, these differences are entirely due to differences in personal tax treatment as a consequence of the assumption (see subsec. 8.3.1) that the corporate tax rate on a given asset is the same whether it is financed abroad or domestically. 
host A

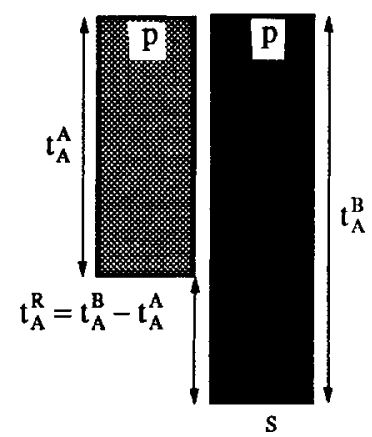

Residence A Residence B

Figure 8.8 The measurement of savings incentives

\subsubsection{The Effect of Savings Incentives on International Capital Flows and Global Efficiency}

International differences in savings incentives, as measured by differences in the tax wedges borne by savers in different countries, will, ceteris paribus, tend to be reflected in lower savings in countries where savers bear the higher tax burden. Accordingly, these differences would contribute to a weaker current account position in those countries, thereby influencing international capital flows.

Differences in savings incentives indicate that capital income taxes violate the so-called principle of capital import neutrality according to which the tax treatment of a given asset should not discriminate between savers residing in different countries (in the absence of externalities). Departures from capital import neutrality are associated with an inefficient allocation of global savings because they drive a wedge between the marginal rates of time preference of different savers. Figure 8.8 illustrates that the cost of postponing marginal consumption for the saver residing in A who faces the lower tax burden exceeds that for the saver who resides in B. Thus, the welfare cost from the allocation of savings to meet a given overall investment level would have been lowered if the less heavily taxed saver were to save less and the more heavily taxed saver were to save more. 


\subsubsection{Host and Residence Tax Wedges: National Welfare Effects}

The personal tax wedge consists of two parts: the withholding tax wedge and the residence tax wedge. The residence country levies the residence tax wedge, while the host country collects, in addition to the corporate tax wedge, the withholding tax wedge. Accordingly, the total host tax wedge is defined as the sum of the corporate and withholding tax wedges. The return after host taxes but before residence taxes is defined as $r_{h}$ (fig. 8.5). It is the return that the residence country collects from the host country and consists of a part received by the private saver (the after-tax return $s$ ) and a part collected by the residence government (the residence tax wedge $t_{R}$ ).

The host-residence split of the total tax wedge provides some insight into the effects of capital income taxation on national welfare. ${ }^{17}$ In particular, the host tax wedge captures the difference between, on the one hand, the national return on a marginal investment, which is measured by the before-tax return $p$, and, on the other hand, the national costs associated with the financing of such an investment by foreign savings, which is represented by the return after host taxes. ${ }^{18}$ Therefore, a positive host tax wedge implies that the host country gains from a marginal investment financed by foreign savings. Similarly, the residence tax wedge measures, at the margin, the net national benefit of financing a foreign investment by domestic savings because it corresponds to the difference between the return after host taxes, which measures the national benefits, and the return after all taxes, which represents the national costs of marginal savings (see subsec. 8.2.2).

\subsection{Economic Environment and Tax Parameters: The United States and Japan}

This study computes tax wedges for the United States and Japan for 1980, 1984, and 1987. Both the macroeconomic environment and tax provisions affect these tax wedges. Subsection 8.4.1 discusses how this study derives the numerical values for the macroeconomic variables in the three years studied. The tax provisions underlying the results are described in subsection 8.4.2.

\subsubsection{The Macroeconomic Environment}

The tax wedge corresponding to debt instruments can be expressed as a function of tax parameters and of the following variables that describe the economic environment: the nominal interest rate in the host country, ${ }^{19}$ expected inflation rates in the host and residence countries, and expected movements in nominal exchange rates. In the case of equity financing, the nominal after-corporate-tax return (including retained earnings) on equity issued in the host country replaces the nominal interest rate as an element in the expressions for the tax wedges. ${ }^{20}$

As regards exchange rate expectations, the study assumes that savers expect movements in nominal exchange rates to reflect inflation differentials. 
The expected rate of inflation in the United States is derived from a survey conducted by Drexel Burnham Lambert on expected inflation ten years ahead. The average of the actual inflation rate in the next three years is used as a proxy for the expected inflation rate in Japan. ${ }^{21}$

The study does not assume that real interest rates are necessarily equalized among countries. Instead, it combines observed long-term nominal interest rates with expected inflation rates to find real interest rates in the two countries. ${ }^{22}$ Long-term interest rates are measured by the rate of return on government bonds. The maturity of the bonds is ten years for the United States and seven years for Japan.

This paper imposes arbitrage at the firm level to find the return on equity. ${ }^{23}$ In particular, it assumes that, for any investment project, the gap between the cost of equity financing and the cost of debt financing is fixed at 5 percentage points. This gap is based on estimates for the costs of equity financing (after corporate tax) during the 1980s that are contained in Hatsopoulos and Brooks (1987). The estimates provided for the 1980s were averaged both over time and over Japan and the United States. ${ }^{24}$

Various other studies link the equity return to the return on debt by imposing an arbitrage condition at the savers' side so that savers earn the same after-tax return on debt and equity. ${ }^{25}$ However, in an open economy framework, arbitrage conditions will generally differ for savers residing in different countries because the tax burden on debt relative to that on equity generally differs across countries. Thus, imposing arbitrage conditions for savers residing in different countries typically yields complete specialization in debt or equity, which is inconsistent with empirical observations. ${ }^{26}$

\subsubsection{Tax Parameters}

Information on key elements of the tax system required for the calculation of the tax wedges is presented in tables 8.4 and 8.5 for the United States and Japan, respectively. (The letters in the columns refer to the sources listed at the end of the tables.)

The corporate tax parameters are based on a typical corporate investment in machinery. The tables reveal that the Japanese tax system has remained relatively stable during the 1980 s. U.S. corporate tax provisions, in contrast, have been altered several times during this period. In particular, the Economic Recovery Tax Act of 1981 (ERTA) greatly liberalized depreciation schedules and provided for more generous investment credits. The Tax Equity and Fiscal Responsibility Act of 1982 (TEFRA) tightened some of these investment incentives. The Tax Reform Act of 1986 reduced the marginal tax rate on corporate income but further tightened investment incentives by repealing the investment credit and making the tax provisions governing depreciation somewhat less generous.

On the personal side, the United States gradually reduced the marginal tax rates on interest and dividend income during the 1980s. However, the Tax 


\begin{tabular}{|c|c|c|c|}
\hline & 1980 & 1984 & 1987 \\
\hline \multicolumn{4}{|l|}{ Tax parameters: } \\
\hline Corporate tax rate & $49.5^{\mathrm{A}}$ & $49.5^{\mathrm{A}}$ & $38.3^{\mathrm{A}}$ \\
\hline Lifetime for depreciation purposes (in years) ${ }^{\mathrm{a}}$ & 10.5 & 4.6 & 6.0 \\
\hline Declining balance rate & 200.0 & 150.0 & 200.0 \\
\hline Investment grant (rate) & $8.7^{\mathrm{B}}$ & $8.9^{\mathrm{B}}$ & $\ldots{ }^{\mathbf{B}}$ \\
\hline \multicolumn{4}{|l|}{ Withholding tax rate on income to nonresidents: } \\
\hline Interest income & 10.0 & & . \\
\hline Dividend income & 15.0 & 15.0 & 15.0 \\
\hline \multicolumn{4}{|l|}{ Personal taxes on: } \\
\hline Interest income & $28.5^{\mathrm{A}}$ & $25.8^{\mathrm{A}}$ & $22.4^{\mathrm{A}}$ \\
\hline Dividend income & $47.5^{\mathrm{A}}$ & $39.6^{\mathrm{A}}$ & $32.0^{\mathrm{A}}$ \\
\hline Exchange gains and losses & $7.0^{\mathrm{A}}$ & $5.9^{\mathrm{A}}$ & $11,0^{\mathrm{A}}$ \\
\hline Capital gains and losses & $7.0^{\mathrm{A}}$ & $5.9^{\mathrm{A}}$ & $11.0^{\wedge}$ \\
\hline $\begin{array}{l}\text { Portion of foreign withholding tax refunded } \\
\text { at the personal level }\end{array}$ & $100.0^{\mathrm{C}}$ & $100.0^{\mathrm{C}}$ & $100.0^{\mathrm{C}}$ \\
\hline \multicolumn{4}{|l|}{ Nontax parameters: } \\
\hline Fraction of new shares in marginal equity financing & $7.4^{\mathrm{A}}$ & $7.4^{\mathrm{b}}$ & $7.4^{\mathrm{b}}$ \\
\hline Rate of economic depreciation & $12.1^{\mathrm{C}}$ & $12.3^{\mathrm{C}}$ & $12.5^{\mathrm{C}}$ \\
\hline Nominal interest rate & 11.5 & 12.5 & 8.4 \\
\hline Expected inflation rate & 8.7 & 6.2 & 5.3 \\
\hline Nominal cost of equity ${ }^{c}$ & 10.8 & 11.3 & 10.2 \\
\hline
\end{tabular}

Sources:

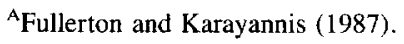

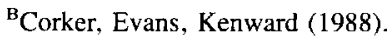

${ }^{\mathrm{C}} \mathrm{Hatsopoulos}$ and Brooks (1987).

${ }^{a} B a s e d$ on a salvage value of 10 percent of purchase value. The most favorable method permitted by the tax code has been used. Accordingly, if after a certain point in time the straight-line method rather than declining balance yields a larger tax deduction, a switch to that method has been assumed.

${ }^{\mathrm{b}}$ Assumed to be the same as in 1980 .

${ }^{\mathrm{C}}$ Based on a gap of 5 percentage points between the costs of equity and debt finance (see main text). The formulas for these costs of finance $r_{f}^{*}$ are presented in the second rows in tables $8 \mathrm{~A} .1$ and 8A.2.

Reform Act of 1986 raised the tax rate on capital gains. The average marginal tax rate on interest income earned by Japanese residents takes into account various methods of tax-exempt savings, such as the Maru-yu accounts. ${ }^{27}$ The marginal tax rate on interest income received from abroad exceeds the marginal rate on interest income from domestic investments because some of the tax-preferred savings, such as postal savings, were not invested abroad. The taxation of dividend income in Japan also favors domestic investment because some tax benefits, such as a 10 percent dividend credit, do not apply to dividends from abroad.

This study focuses on portfolio rather than direct investments (see sec. 8.1). Accordingly, residence countries neither credit nor levy corporate taxes 
Table 8.5

Japan: Parameters (\%)

\begin{tabular}{|c|c|c|c|}
\hline & 1980 & 1984 & 1987 \\
\hline \multicolumn{4}{|l|}{ Tax parameters: } \\
\hline \multicolumn{4}{|l|}{ Corporate tax rate: } \\
\hline Retained earnings & 52.6 & 56.1 & 54.7 \\
\hline Dividends & 42.1 & 45.5 & 44.2 \\
\hline Lifetime for tax purposes (in years) $^{\mathrm{a}}$ & 11.0 & 11.0 & 11.0 \\
\hline Declining balance rate & 100.0 & 100.0 & 100.0 \\
\hline Investment grant (rate) & $\ldots$ & $\ldots$ & $\ldots$ \\
\hline \multicolumn{4}{|l|}{ Withholding tax rate on income to nonresidents: } \\
\hline Interest income & 10.0 & 10.0 & 10.0 \\
\hline Dividend income & 15.0 & 15.0 & 15.0 \\
\hline \multicolumn{4}{|l|}{ Personal taxes on: } \\
\hline Domestic interest income & 8.2 & 7.1 & 7.1 \\
\hline Domestic dividend income & 25.8 & 25.8 & 25.8 \\
\hline Foreign interest income & 11.1 & 10.1 & 9.8 \\
\hline Foreign dividend income & 47.9 & 47.9 & 47.9 \\
\hline Exchange gains and losses & $\ldots$ & $\ldots$ & $\ldots$ \\
\hline Capital gains and losses & $\ldots$ & . & $\ldots$ \\
\hline \multicolumn{3}{|l|}{ Portion of foreign withholding tax refunded } & 100.0 \\
\hline \multicolumn{4}{|l|}{ Nontax parameters: } \\
\hline Fraction of new shares in marginal equity financing & $8.7^{\mathrm{C}}$ & $8.7^{\mathrm{b}}$ & $8.7^{\mathrm{b}}$ \\
\hline Rate of economic depreciation & $15.1^{\mathrm{A}}$ & $15.3^{\mathrm{A}}$ & $15.5^{\mathrm{A}}$ \\
\hline Nominal interest rate & 9.2 & 6.8 & 4.2 \\
\hline Expected inflation rate & 5.2 & 1.6 & .9 \\
\hline Nominal cost of equity ${ }^{c}$ & 9.4 & 8.1 & 7.0 \\
\hline
\end{tabular}

Sources:

${ }^{\text {A}}$ Hatsopoulos and Brooks (1987).

${ }^{B}$ Kikutani and Tachibanaki (1987).

${ }^{\mathrm{C}}$ Shoven and Tachibanaki (1985).

${ }^{a}$ Based on a salvage value of 10 percent of purchase value.

${ }^{b}$ Assumed to be the same as in 1980 .

${ }^{c}$ Based on a gap of 5 percentage points between the costs of equity and debt finance (see main text). The formulas for these costs of finance $r_{f}^{*}$ are presented in the second rows in tables 8A.1 and $8 \mathrm{~A} .2$

(see subsec. 8.3.1). However, savers are assumed to receive full credit for any withholding taxes levied by the host government on their personal income. $^{28}$

\subsection{Tax Wedges in the 1980s: The U.S.-Japan Case}

This section interprets the empirical estimates for the tax wedges in 1980 , 1984, and 1987 contained in tables 8.6-8.8. The two panels in these tables contain the results for, respectively, a debt and an equity-financed investment. Tables 8.6 and 8.7 present the tax wedges on assets located in, 


\begin{tabular}{|c|c|c|c|c|c|c|c|c|c|}
\hline \multirow[b]{2}{*}{ Tax Wedges } & \multicolumn{3}{|c|}{$\begin{array}{c}\text { Saver Residing } \\
\text { in Japan }\end{array}$} & \multicolumn{3}{|c|}{$\begin{array}{l}\text { Saver Residing in } \\
\text { the United States }\end{array}$} & \multicolumn{3}{|c|}{$\begin{array}{c}\text { Saver Residing in Japan } \\
\text { Relative to Saver Residing in } \\
\text { the United States }{ }^{\mathbf{a}}\end{array}$} \\
\hline & 1980 & 1984 & 1987 & 1980 & 1984 & 1987 & 1980 & 1984 & 1987 \\
\hline \multicolumn{10}{|l|}{ Debt instrument: } \\
\hline Total & -1.36 & -.67 & -.34 & .75 & .87 & .78 & -2.12 & -1.54 & -1.12 \\
\hline Corporate & -2.12 & -1.16 & -.64 & -2.12 & -1.16 & -.64 & $\ldots$ & $\ldots$ & $\cdots$ \\
\hline Personal & .76 & .48 & .30 & 2.87 & 2.03 & 1.42 & -2.12 & -1.54 & -1.12 \\
\hline Total & -1.36 & -.67 & -.34 & .75 & .87 & .78 & -2.12 & -1.54 & -1.12 \\
\hline Host & -2.12 & -1.16 & -.64 & -1.20 & -.47 & -.22 & -.92 & -.68 & -.42 \\
\hline Residence & .76 & .48 & .30 & 1.95 & 1.35 & 1.00 & -1.19 & -.86 & -.70 \\
\hline \multicolumn{10}{|c|}{ Equity instrument: } \\
\hline Total & 6.68 & 7.77 & 6.55 & 7.64 & 8.56 & 7.77 & -.96 & -.79 & -1.22 \\
\hline Corporate & 6.59 & 7.63 & 6.42 & 6.59 & 7.63 & 6.42 & $\ldots$ & $\ldots$ & $\cdots$ \\
\hline Personal & .09 & .14 & .14 & 1.05 & .93 & 1.36 & -.96 & -.79 & -1.22 \\
\hline Total & 6.68 & 7.77 & 6.55 & 7.64 & 8.56 & 7.77 & -.96 & -.79 & -1.22 \\
\hline Host & 6.59 & 7.63 & 6.42 & 6.64 & 7.71 & 6.50 & -.05 & -.08 & -.08 \\
\hline Residence & .09 & .14 & .14 & 1.00 & .85 & 1.28 & -.90 & -.71 & -1.14 \\
\hline
\end{tabular}

Source: Authors' calculations.

a The column for each of the three years is computed by subtracting the results for a U.S. saver from those for a Japanese saver. 


\begin{tabular}{|c|c|c|c|c|c|c|c|c|c|}
\hline \multirow[b]{2}{*}{ Tax Wedges } & \multicolumn{3}{|c|}{$\begin{array}{c}\text { Saver Residing } \\
\text { in Japan }\end{array}$} & \multicolumn{3}{|c|}{$\begin{array}{l}\text { Saver Residing in } \\
\text { the United States }\end{array}$} & \multicolumn{3}{|c|}{$\begin{array}{c}\text { Saver Residing in Japan } \\
\text { Relative to Saver Residing in } \\
\text { the United States }{ }^{\mathrm{a}}\end{array}$} \\
\hline & 1980 & 1984 & 1987 & 1980 & 1984 & 1987 & 1980 & 1984 & 1987 \\
\hline \multicolumn{10}{|l|}{ Debt instrument: } \\
\hline Total & -4.30 & -5.29 & -1.67 & -2.31 & -3.32 & -.61 & -1.99 & -1.97 & -1.06 \\
\hline Corporate & -5.57 & -6.55 & -2.49 & -5.57 & -6.55 & -2.49 & $\ldots$ & $\ldots$ & $\ldots$ \\
\hline Personal & 1.27 & 1.26 & .82 & 3.27 & 3.23 & 1.88 & -1.99 & -1.97 & -1.06 \\
\hline Total & -4.30 & -5.29 & -1.67 & -2.31 & -3.32 & -.61 & -1.99 & -1.97 & -1.06 \\
\hline Host & -4.43 & -6.55 & -2.49 & -5.57 & -6.55 & -2.49 & 1.15 & $\ldots$ & $\ldots$ \\
\hline Residence & .13 & 1.26 & .82 & 3.27 & 3.23 & 1.88 & -3.14 & -1.97 & -1.06 \\
\hline \multicolumn{10}{|c|}{ Equity instrument: } \\
\hline Total & 1.83 & .84 & 1.98 & 2.58 & 1.46 & 3.01 & -.74 & -.61 & -1.02 \\
\hline Corporate & 1.76 & .66 & 1.81 & 1.76 & .66 & 1.81 & $\ldots$ & $\ldots$ & $\ldots$ \\
\hline Personal & .07 & .18 & .17 & .82 & .80 & 1.19 & -.74 & -.61 & -1.02 \\
\hline Total & 1.83 & .84 & 1.98 & 2.58 & 1.46 & 3.01 & -.74 & -.61 & -1.02 \\
\hline Host & 1.78 & .72 & 1.87 & 1.76 & .66 & 1.81 & .02 & .06 & .05 \\
\hline Residence & .05 & .12 & .12 & .82 & .80 & 1.19 & -.77 & -.67 & -1.08 \\
\hline
\end{tabular}

Source: Authors' calculations.

a The column for each of the three years is computed by subtracting the results for a U.S. saver from those for a Japanese saver. 
Taxation of Assets Located in Japan Relative to the Taxation of Assets Located in the United States, 1980-87 (in percentage points)

\begin{tabular}{|c|c|c|c|c|c|c|c|c|c|}
\hline \multirow[b]{2}{*}{ Tax Wedges } & \multicolumn{3}{|c|}{$\begin{array}{l}\text { Saver Residing } \\
\text { in Japan }\end{array}$} & \multicolumn{3}{|c|}{$\begin{array}{l}\text { Saver Residing in } \\
\text { the United States }\end{array}$} & \multicolumn{3}{|c|}{$\begin{array}{l}\text { Saver Residing in } \\
\text { Japan relative to } \\
\text { Saver Residing in } \\
\text { the United States }\end{array}$} \\
\hline & 1980 & 1984 & 1987 & 1980 & 1984 & 1987 & 1980 & 1984 & 1987 \\
\hline \multicolumn{10}{|l|}{ Debt instrument: } \\
\hline Total & 2.94 & 4.62 & 1.33 & 3.06 & 4.20 & 1.40 & -.12 & .42 & -.07 \\
\hline Corporate & 3.46 & 5.40 & 1.85 & 3.46 & 5.40 & 1.85 & $\ldots$ & & \\
\hline Personal & -.52 & -.78 & -.52 & -.39 & -1.20 & -.45 & -.12 & .42 & -.07 \\
\hline Total & 2.94 & 4.62 & 1.33 & 3.06 & 4.20 & 1.40 & -.12 & .42 & -.07 \\
\hline Host & 2.31 & 5.40 & 1.85 & 4.38 & 6.08 & 2.27 & -2.07 & -.68 & -.42 \\
\hline Residence & .63 & -.78 & -.52 & -1.32 & -1.88 & -.87 & 1.95 & 1.10 & .35 \\
\hline \multicolumn{10}{|c|}{ Equity instrument: } \\
\hline Total & 4.85 & 6.93 & 4.57 & 5.06 & 7.10 & 4.77 & -.21 & -.18 & -.20 \\
\hline Corporate & 4.83 & 6.96 & 4.61 & 4.83 & 6.96 & 4.61 & $\ldots$ & $\ldots$ & \\
\hline Personal & .02 & -.04 & -.04 & .23 & .14 & .16 & -.21 & -.18 & -.20 \\
\hline Total & 4.85 & 6.93 & 4.57 & 5.06 & 7.10 & 4.77 & -.21 & -.18 & -.20 \\
\hline Host & 4.81 & 6.91 & 4.55 & 4.88 & 7.05 & 4.68 & -.08 & -.14 & -.13 \\
\hline Residence & .04 & .02 & .02 & .18 & .06 & .08 & -.13 & -.03 & -.07 \\
\hline
\end{tabular}

Source: Authors' calculations.

Note: This table is computed by subtracting the results in table 8.7 from the corresponding results in table 8.6.

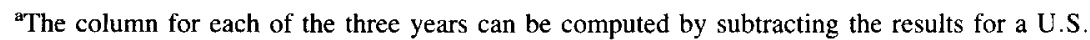
saver from those for a Japanese saver.

respectively, Japan and the United States. The first three columns in tables 8.6 and 8.7 show how a Japanese saver was taxed. The tax treatment of a U.S. saver is presented in the next three columns. The last three columns are computed as the difference between the column for the Japanese saver and the column for the U.S. saver. Thus, the last three columns in tables 8.6 and 8.7 measure relative savings incentives because they reveal how, for a given asset, the tax treatment of a Japanese saver differed from that of a saver residing in the United States (see subsec. 8.3.4 and fig. 8.8). Table 8.8 measures how the tax system may have affected international capital flows through its effect on investment incentives; it compares, for a given saver, the tax treatment of investments in Japan with that of investments in the United States (see subsec. 8.3.2 and fig. 8.6). This table is computed by subtracting the results contained in table 8.7 from the corresponding results contained in table 8.6.

In each column, the total tax burden is broken down in two ways. First, the total tax wedge is the sum of the corporate tax wedge and the personal tax wedge. Second, the total tax wedge consists of the host tax wedge and 
the residence tax wedge. For investments financed by savers residing in the same country, the distinction between host and residence tax wedges is irrelevant because the host country and residence country are one and the same. For these local investments, the host tax wedge is given by the corporate tax wedge.

The disaggregation of the total tax wedge into host and residence tax wedges provides information on national welfare effects (see subsec. 8.3.6). Moreover, comparing the host tax wedge for a Japanese asset with that for a U.S. asset measures the investment incentive for a saver who does not pay any personal taxes except for those withheld abroad. Savers pay only these personal taxes if they are tax exempt or if they evade taxes.

The rest of this section is organized as follows. Subsection 8.5.1 analyzes tax incentives for international capital flows by investigating, respectively, investment and savings incentives. How capital income taxation affects global efficiency by distorting the international and intertemporal allocation of resources is explored in subsection 8.5.2. Finally, subsection 8.5.3 analyzes national welfare effects.

\subsubsection{Tax Incentives for International Capital Flows}

\section{Investment Incentives}

The positive numbers in (the first six columns of) the first rows of the two panels in table 8.8 indicate that the tax burden on assets located in Japan exceeded the tax burden on assets located in the United States. Accordingly, taxes encouraged capital flows from Japan to the United States by favoring investments in the United States.

The breakdown over the corporate and personal tax wedges reveals which factors are behind the tax incentives for investments in the United States. For the debt case, the corporate-personal split is contained in the second and third rows of the first panel in table 8.8. These rows show that the larger investment incentives in the United States are entirely the consequence of a more favorable corporate tax treatment in the United States, which can be explained by more liberal depreciation rules, more generous investment credits, and, for debt-financed investments, a higher inflation rate that raises the value of the deductibility of nominal interest payments. ${ }^{29}$

Unlike corporate taxes, personal taxes in both Japan and the United States discriminated against debt-financed investments in the United States for two reasons. ${ }^{30} \mathrm{~A}$ major reason is the relatively low expected inflation rate in Japan. Accordingly, under the assumption that exchange rates reflected inflation differentials, the yen was expected to appreciate relative to the dollar. Consequently, Japanese assets yielded part of their expected returns to U.S. savers in capital gains, which the U.S. personal tax system treated favorably relative to nominal interest income. In addition, Japanese savers could not deduct the expected capital losses on U.S. assets from their personal tax liabilities, while they were fully taxed on the higher nominal 
returns on these assets. A second explanation for the higher personal tax wedge on U.S. assets faced by Japanese residents is that some of the tax-sheltered forms of Japanese savings were not allowed to flow abroad (see subsec. 8.4.2).

The movements of the relative investment incentives over time reveal that international differentials in investment incentives first rose between 1980 and 1984 and then fell in 1987 . These developments were due mainly to tax policy in the United States, which first liberalized its investment incentives but later tightened them (see subsec. 8.4.2).

In the case of debt financing, the 1984 increase in the favorable treatment of U.S. investment is particularly dramatic when measured by the change in the relative host tax wedge contained in the fifth row of table 8.8. When the United States repealed the withholding tax on interest income to foreigners in 1984, it became a more attractive investment location for those savers who could not fully credit the withholding tax against their residence tax liabilities.

\section{Savings Incentives}

The negative numbers in the last three columns of the first rows of the two panels in table 8.6 reveal that, for an asset located in Japan, the U.S. saver faced the heaviest tax burden, especially on debt instruments. The corresponding numbers in table 8.7 show that this was also the case for an asset located in the United States. Therefore, if higher after-tax returns raise savings, the tax systems harmed the relative savings performance of the United States. ${ }^{31}$ Accordingly, in addition to investment incentives, savings incentives may also have encouraged U.S. capital inflows.

Except for an increase in the relatively favorable tax treatment of equity income earned by Japanese savers in 1987, international differences in tax incentives for savings fell during the 1980s. Two main factors explain the increasing harmonization of tax incentives. First, falling inflation rates and nominal interest rates tended to reduce the absolute value of the tax wedges. Second, as regards debt financing, the United States reduced its personal income tax rates during this period. ${ }^{32}$

\subsubsection{Global Welfare Effects}

This subsection uses the calculated tax wedges to assess how capital income taxation may have influenced the international allocation of savings and investment as well as the intertemporal allocation of resources between the present and the future.

\section{International Allocation of Investment and Saving}

The results contained in table 8.8 and discussed above in subsection 8.5.1 revealed that taxes favored investment in the United States over investment in Japan. In the absence of externalities, these differential investment incentives would have interfered with an efficient allocation of the world 
capital stock. In particular, the relatively favorable treatment of investment in the United States may have caused the social benefit of marginal U.S. investment to fall below the marginal productivity of investment in Japan. Consequently, reallocating capital away from the United States to Japan would have raised world welfare.

The results discussed in subsection 8.5.1 indicated that, compared with Japanese residents, U.S. residents were taxed more heavily on their savings. The less favorable tax treatment of U.S. savings may have contributed to an inefficient allocation of world savings to the extent that world welfare would have risen if the share of U.S. savings in worldwide savings had been larger.

Developments of the tax wedges over time suggest that differential tax distortions in the international distribution of savings fell during the 1980s. The potential tax distortions in the international allocation of capital, in contrast, rose during 1980-84, after which they also decreased.

\section{Intertemporal Allocation of Resources}

The global intertemporal distortions from capital taxation depend on the total tax wedge. The first rows in the second panels of tables 8.6 and 8.7 reveal that the total tax wedges levied on marginal equity investments were positive. This implies that the net benefits of a marginal equity investment exceeded the social costs associated with financing such an investment, once again in the absence of externalities. Consequently, a marginal increase in equity investment would have raised global welfare.

In contrast to their treatment of equity investments, tax systems typically subsidized marginal debt investments. The only marginal debt investment carrying a positive tax wedge was one located in Japan and financed by a U.S. saver. The debt investment enjoying the highest subsidy was one located in the United States and financed by a Japanese saver. These results are explained as follows. The personal-corporate split (second and third rows of the first panels in tables 8.6 and 8.7) reveals that debt instruments were subsidized at the corporate level but taxed at the personal level. Whereas assets located in the United States were more heavily subsidized by the corporate tax system, Japanese savers were taxed lightly at the personal level compared to savers residing in the United States. Only if a U.S. saver, who suffered from a relatively high personal tax burden, financed an asset located in Japan, which enjoyed a relatively small subsidy at the corporate level, was the personal tax large enough to offset the subsidy at the corporate level. Thus, a marginal debt investment, in the absence of externalities, would improve world welfare only if it were located in Japan and financed by a U.S. resident.

The total tax wedges indicate that the absolute values of net subsidies to debt financing for assets located in the United States, after remaining broadly constant between 1980 and 1984, decreased during the period 1984-87. Both the falling expected inflation rate and the repeal of some of the investment incentives in the United States played a role in explaining the 
mitigation of these intertemporal distortions. After rising between 1980 and 1984 , the net tax burdens on equity assets located in Japan fell during 1984-87 to levels close to those in 1980 (table 8.6), which is explained in part by movements in the corporate tax rate in Japan. Equity assets located in the United States, in contrast, faced increased tax burdens between 1984 and 1987 after these tax burdens had fallen during 1980-84 (table 8.7).

\subsubsection{National Welfare Effects}

The host-residence split of the tax wedges (fifth and sixth rows of the two panels in tables 8.6 and 8.7) provides information on how marginal crossborder investments affect national welfare (see subsec. 8.3.6). The fifth rows of the two panels in tables 8.6 and 8.7 indicate that, at the margin, host governments subsidized debt investments. On equity investments, in contrast, they levied taxes. Thus, host countries tended to lose from foreign-financed debt investments but gained from equity capital inflows. The reason is that host countries allow interest expenses to be deducted for corporate tax purposes. Consequently, while the corporate tax acts as a withholding tax for equity income, it fails to withhold interest income on debt.

The net subsidy granted to debt capital inflows was largest in the United States. Whereas the Japanese subsidy fell during the 1980s, that in the United States rose during 1980-84. In 1987, however, the U.S. subsidy dropped below its 1980 level.

\subsection{Conclusions}

\subsubsection{Some Limitations of the Present Study}

Tax wedges were estimated separately for investments financed through the issuance of either debt or equity. While this procedure covers the two extremes, it does not address cases where the marginal investment is financed through a mix of debt and equity, which could change some of the results obtained. In particular, a greater preference for debt financing in Japan relative to the United States would reduce the relative incentives to invest in the United States. There is, however, considerable uncertainty as to the actual debt-equity mix of the marginal investment in a particular country. The data are unavailable, and, moreover, the ratio itself could vary depending on the residence of the saver financing the investment. In any event, by presenting the two extremes, this study provides sufficient information to facilitate the computation of the tax wedges for any selected debt-equity ratio.

Another limitation is that the tax wedges were computed only for corporate investments in machinery. The method developed in the study could be employed for a more comprehensive assessment that would also cover other investments, including those in inventories and business structures. However, as many of the qualifications that would be introduced 
concern the tax treatment of depreciation, and as these were substantially more generous in the United States than in Japan, particularly in the early 1980 s, the qualitative ranking of the savings and investment incentives may not change.

A further limitation is the exclusive focus on corporate investment. Other forms of capital flow, for example, investment in government securities, acquisition of real estate, and buyouts of companies, are of increasing importance. While a fuller study is needed to account adequately for the role of tax factors in influencing these capital flows, the information presented in the study permits some inferences for savings through government securities. Income from such securities are subject to a host-withholding tax, if levied, and to the residence personal income tax. As the latter is substantially higher in the United States than in Japan, the U.S. saver was taxed more heavily than the Japanese saver irrespective of whether he invested in U.S. or Japanese government securities. Also in this case, the tax systems hurt the savings performance of the United States relative to Japan. However, the differences in tax incentives for investing in government securities decreased during the 1980s.

\subsubsection{Some Implications for Savings-Investment Balances}

The tax wedges obtained for Japanese savers investing in Japan can be compared with those for U.S. savers investing in the United States, as has been done in some studies. Such a comparison may be useful if capital is not mobile internationally. This appears to have been characteristic of Japanese capital markets before a major liberalization occurred in the early 1980s. As was noted in section 8.2 , in a relatively closed capital market, the composition of the tax wedge needs to be known in order to establish tax effects on real interest rates. Larger corporate tax factors and lower personal tax factors in Japan relative to those in the United States may have contributed to a lower Japanese real interest rate level, although the actual outcome for domestic interest rates may also have been affected by other demands for credit, especially from the public sector. As figure 8.9 demonstrates, the general government fiscal deficit was fairly sizable in Japan up to about 1981 but declined substantially thereafter. Over the same period, real interest rate levels in Japan, which in the years immediately preceding were higher, fell below those in the United States (fig. 8.10). If the Japanese capital market had not been liberalized in the early $1980 \mathrm{~s}$, the growing Japanese savings surpluses would have been bottled up within the domestic economy. Accordingly, the equilibrating responses may well have involved greater deflation, with Japanese real interest rates declining further. However, the major liberalization of Japanese capital markets provided a vent for the excess savings by allowing more capital outflows.

Over this period, developments in the United States accommodated the growing Japanese savings surpluses. The U.S. fiscal balance moved into persistent and substantial deficit (see fig. 8.11). If the international capital 


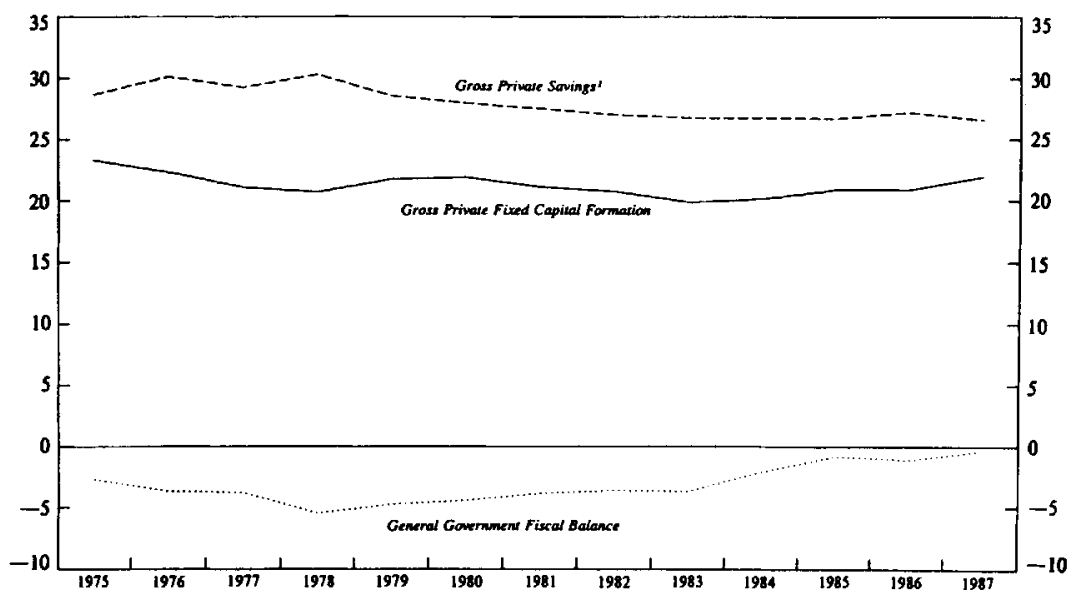

Fig. 8.9 Fiscal balance, private savings, and investment patterns in Japan, 1975-87 (in percentage of GNP)

Source: OECD, National Accounts, and staff calculations.

${ }^{1}$ Private savings defined as the sum of household and corporate savings.

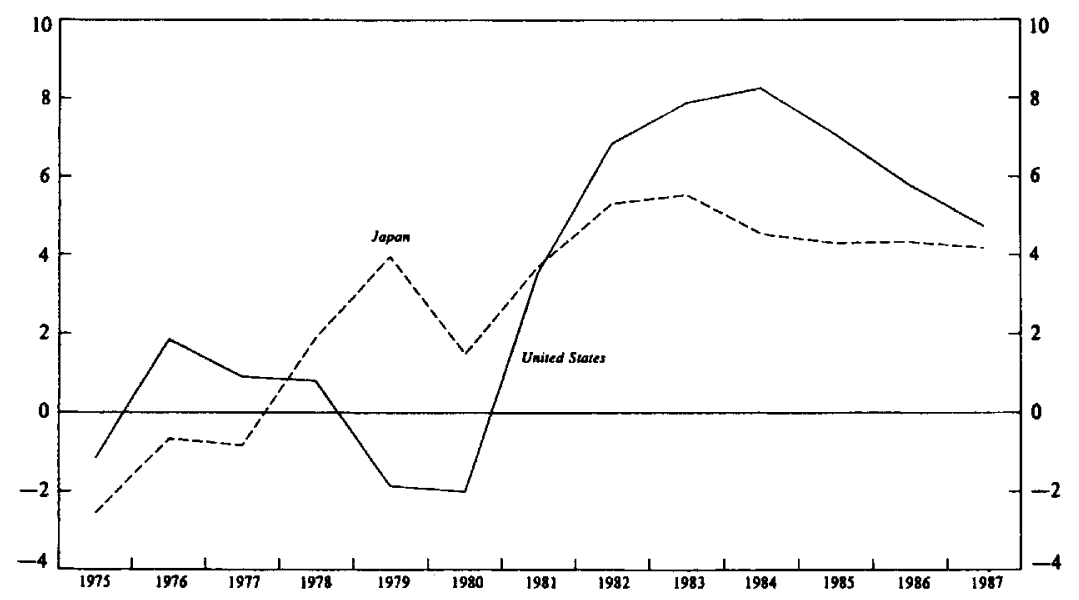

Fig. 8.10 Real long-term interest rates in Japan and the United States, 197587 (in percentage per annum; nominal interest rate on long-term government bonds deflated by CPI inflation rate)

Source: IMF, IFS.

market had not become more integrated and resources from abroad had not become available, ensuing adjustments would most likely have added to inflationary pressures in the United States, accompanied by rising real interest rates crowding out investment in the United States in a manner reminiscent of an earlier episode in the late 1960s. The crowding out of 


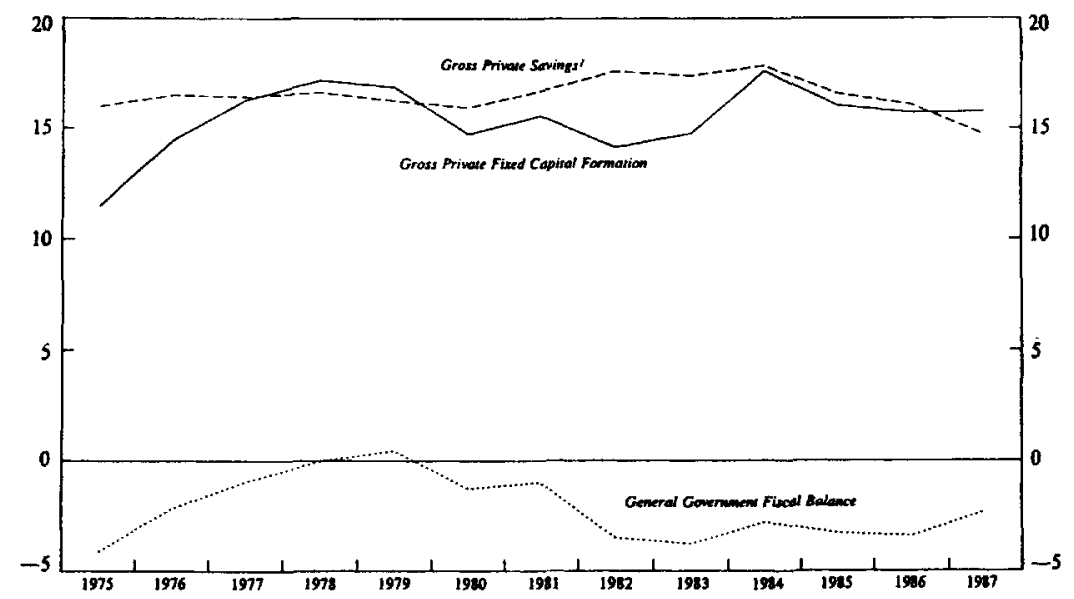

Fig. 8.11 Fiscal balance, private savings, and investment patterns in the United States, 1975-87 (in percentage of GNP)

Source: U.S. Department of Commerce, Survey of Current Business.

${ }^{1}$ Private savings defined as the sum of household and corporate savings.

investment was also avoided by the more liberal U.S. investment incentives introduced in 1981, which prevented higher real interest rates from harming investment.

Without a detailed econometric study, it is difficult to assess the contribution of tax factors to capital flows, although some broad inferences can be drawn. In 1982, the net outflow of private capital from the United States was reversed (table 8.1). At the same time, a positive real interest differential in favor of the United States emerged (fig. 8.10), and the value of the U.S. dollar rose. These phenomena are consistent with more generous tax incentives for investment in the United States between 1981 and 1984 (table 8.8). These incentives put upward pressure on the U.S. interest rates, thereby attracting foreign capital and raising the value of the dollar. It is, perhaps, no coincidence that the sharp decline in the tax differential favoring investment in the United States in 1986 is associated with a major reduction in net private capital inflows in 1987, forcing official intervention to finance a much larger share of the U.S. current account deficit, a narrowing of the real interest differential, and downward pressure on the U.S. dollar.

\subsubsection{The Role of Tax Coordination}

It is interesting to inquire, in the context of the study's findings, whether the systems of capital income taxes were adequately coordinated. A widespread presumption is that tax systems should be neutral and not distort 
the accumulation and allocation of capital. In an international context, this requires that before-tax marginal products on capital and after-tax returns on savings are equalized across countries. It is a short but contentious step to conclude from this that tax systems in different countries should, therefore, be harmonized. In the context of this study, complete harmonization occurs if the different tax wedges are equalized so that the tax incentives provided are the same for savers and investors in different countries.

However, in practice, complete tax harmonization is elusive, and an attempt to enforce it may well reduce welfare. A greater concern with environmental issues or different perceptions of national contingencies and other externalities may lead to diverse needs for the accumulation of capital and its allocation. Intercountry differences in capital income taxes may, therefore, be necessary to accommodate such needs. There is, nevertheless, a role for tax coordination in order to ensure that the interaction of national tax policies does not unduly damage global efficiency. In particular, tax systems, and the interactions among them, should not excessively bias savings and investment incentives in favor of any one country, thereby misallocating capital. However, the complex considerations involved suggest that circumspection should be used in determining what is an "excessive" bias.

The more generous investment incentives introduced by the United States in 1981 may have acted to offset the adverse effects on investment of the sharp rise in real interest rates. Nevertheless, the reduction in capital income taxes contributed to the decline in income tax collections from 12.9 percent of GDP in 1980 to 9.8 percent in 1986, more than matching the increase in the general government fiscal deficit from 1.3 percent of GDP to 3.4 percent of GDP over the same period. To the extent that the persistent fiscal deficit preempts a significant part of the world's pool of savings and keeps real interest rates high, a vicious circle is generated: cuts in capital income taxes are required to offset the adverse effects on the cost of capital from their deficit-enhancing effects. In increasingly integrated world financial markets, such a policy generates a widening imbalance between domestic savings and investment, resulting in large capital inflows and shifts in exchange rates. Moreover, the required subsidies to investments tend to be inconsistent with the requirements for global and national efficiency. An alternative policy of maintaining 1980 tax levels could have lowered the fiscal deficit and lessened the upward pressures on real interest rates. Such a policy would have protected private investment without having to rely on capital inflows and investment subsidies that were distorting the international allocation of capital. Some adjustment at the margin in the early 1980s, involving an increase in savings incentives for residents of the United States and a decrease in the fiscal deficit, financed by a reduction in the generous investment incentives through increases in corporate taxation (as occurred in 1986) might have been appropriate. 
A critical consideration is that, as economies become more integrated, the alleviating role of purely domestic adjustment mechanisms is reduced, for example, through the effect of imbalances on domestic interest rates. Consequently, the distortionary effects of taxes on global and national welfare as well as on international capital flows become more pronounced. If these distortions are to be mitigated, policymakers must pay increasing attention to the international implications of their domestic tax policies.

\section{Appendix \\ Derivation of the Tax Wedges}

This appendix describes how one can derive the real rates of return and the tax wedges introduced in section 8.3 from expected inflation rates, nominal interest rates (for a debt instrument), and nominal equity returns (for an equity instrument).

Tables 8A.1 and 8A.2 present these tax wedges for a debt- and equity-financed investment, respectively. Table $8 \mathrm{~A} .3$ defines the different variables and lists the tax parameters required to find the wedges presented in tables $8 \mathrm{~A} .1$ and $8 \mathrm{~A} .2 .^{33} \mathrm{~A}$ variable marked with an asterisk refers to the host country. A variable without an asterisk relates to the residence country. ${ }^{34}$

The real market rate of return $r^{*}$, which is contained in the first row of the tables, is the return that is earned after all corporate taxes but before any personal tax. The second row in the tables presents the real cost of finance $r_{f}^{*}$. Investors (usually the firm) adopt this rate as the discount rate at which they compare all receipts and outlays (after corporate tax) occurring at different points in time. The nominal after-tax cost to debt finance is $i^{*}\left(1-u_{f}^{*}\right)$, where $u_{f}^{*}$ is the effective (corporate) tax rate at which the investor can deduct interest payments in calculating taxable income. In the absence of a split rate system (i.e., $u_{s}^{*}=u_{k}^{*}$ ), the real cost of equity finance is simply the market return on equity because, in contrast to interest payments, equity returns are not deductible from taxable income.

The cost of capital $p^{*}$, given in the third row of the tables, is the required real rate of return before corporate income taxes are levied and tax allowances are granted. The expression for $p^{*}$ is derived from the equality between the marginal benefit and the marginal cost on an investment project:

$$
\left(1-u_{k}^{*}\right)\left(p^{*}+\delta^{*}\right)=\left(1-A^{*}\right)\left(r_{f}^{*}+\delta^{*}\right) .
$$

Here, $\delta^{*}$ is the exponential rate of economic depreciation. The left-hand side of (A1) corresponds to the revenues after corporate income tax has been levied on the user cost of capital $p^{*}+\delta^{*}$ at an effective rate of $u_{k}^{*} \cdot{ }^{35}$ For a marginal investment project, these revenues are equal to the real marginal costs 
of holding capital, which are represented by the right-hand side of (A1). These costs amount to the after-tax cost of a unit of investment $\left(1-A^{*}\right)$ times the sum of the after-tax financing costs $r_{f}^{*}$ and the costs of depreciation.

Following King and Fullerton $(1984,19), A^{*}$ denotes the present value of investment grants and depreciation allowances on a project with a cost (before tax allowances) of unity. This parameter reduces the after-tax cost of a unit of capital. The fourth row in the tables shows that this paper accounts for three forms of grants and allowances: standard depreciation allowances, immediate expensing (or free depreciation) and cash grants.

The fifth row contains the corporate tax wedge $t_{c}^{*}$. This gap between the cost of capital and the market return corresponds to the "investment tax wedge" in Sorenson (1987), Sinn (1987), and Boadway, Bruce, and Mintz $(1984,1987) .^{36}$ These papers use the investment tax wedge as a measure for the incentive to invest in a small open economy that takes the real market return $r^{*}$ as given. ${ }^{37}$

The sixth and seventh rows in the tables contain, respectively, the real return after withholding taxes $r_{w}^{*}$ and the withholding tax wedge $t_{w}^{*}$. The withholding tax wedge on dividends includes the effects of provisions to mitigate the double taxation of dividends, such as a split rate or imputation system. Withholding taxes on dividend income influence investment incentives only if the firm uses new share issues to finance marginal investment (see table 8A.2). ${ }^{38}$

The eighth row in the tables aggregates the tax wedges for all host taxes. This host tax wedge $t_{h}^{*}$ is important in determining the national welfare effects associated with capital taxation because it corresponds to the wedge between the social return on capital, which at the margin is equal to the cost of capital $p^{*}$, and the cost of capital to the host country as a whole, $r_{w}^{*}$.

The after-tax return, which is presented in the ninth row in the tables, affects the incentive to save. The total tax wedge, contained in the twelfth row, reflects the total effect of the tax system on these incentives. This wedge is important in determining the worldwide intertemporal efficiency costs resulting from capital taxation. It corresponds to the wedge between the social return on marginal investment $p^{*}$ and the social costs associated with the financing of such an investment $s$.

The residence tax factor for debt instruments, contained in the tenth row in table 8A.1, depends on how the residence country credits foreign withholding taxes on dividend and interest income. The parameters $\theta_{d}$ and $\theta_{i}$ summarize these crediting arrangements for, respectively, dividend and interest income. Relative expected inflation rates may affect the residence tax burden imposed on domestic debt instruments relative to that imposed on foreign debt if the tax rate on interest income exceeds the tax rate on exchange rate gains and losses. ${ }^{39}$ In that case, the residence tax burden on domestic debt relative to that on foreign debt generally rises if the expected domestic inflation rate increases relative to the expected foreign rate of inflation. ${ }^{40}$ 
Real Rate of Return or Tax Wedge

Symbol
(1) Market return
(2) Discount rate investor
(3) Cost of capital

$r^{*}$
$r_{f}^{*}$
$p^{*}$

(4) Effective subsidy on capital goods

(5) Corporate tax wedge

(6) Return after withholding tax

(7) Withholding tax wedge

(8) Host tax wedge

(9) Return after tax

(10) Residence tax wedge

(11) Personal tax wedge

(12) Total tax wedge
Derivation

Expression

$$
\begin{aligned}
& i^{*}-\pi^{*} \\
& \left(1-u_{f}^{*}\right) i^{*}-\pi^{*} \\
& \frac{\left(1-A^{*}\right)}{\left(1-u_{k}^{*}\right)}\left[\left(1-u_{f}^{*}\right) i^{*}-\pi^{*}+\delta^{*}\right]-\delta^{*} \\
& f_{1}^{*} u_{d}^{*} A_{d}^{*}+f_{2}^{*} u_{d}^{*}+f_{3}^{*} g^{*} \\
& {\left[\frac{\left(1-A^{*}\right)}{\left(1-u_{k}^{*}\right)}\left(u_{k}^{*}-u_{f}^{*}\right)-A^{*}\right] i^{*}+\left[\frac{A^{*}-u_{k}^{*}}{\left(l-u_{k}^{*}\right)}\right]\left(\pi^{*}-\delta^{*}\right)} \\
& \left(1-w_{i}^{*}\right) i^{*}-\pi^{*} \\
& w_{i}^{*} i^{*} \\
& {\left[\frac{\left(1-A^{*}\right)\left(u_{k}^{*}-u_{f}^{*}\right)}{\left(1-u_{k}^{*}\right)}+w_{i}^{*}-A^{*}\right] i^{*}+\left[\frac{A^{*}-u_{k}^{*}}{\left(l-u_{k}^{*}\right)}\right]\left(\pi^{*}-\delta^{*}\right)} \\
& \left(1-m_{i}\right) \theta_{i}\left(1-w_{i}^{*}\right) i^{*}-(1-z) \pi^{*}-z \pi \\
& \left.\left[1-m_{i}\right) \theta_{i}\right]\left(1-w_{i}^{*}\right) i^{*}+z\left(\pi-\pi^{*}\right) \\
& {\left[1-\left(1-m_{i}\right) \theta_{i}\left(1-w_{i}^{*}\right)\right] i^{*}+z\left(\pi-\pi^{*}\right)} \\
& {\left[\frac{\left(1-A^{*}\right)\left(u_{k}^{*}-u_{f}^{*}\right)}{\left(l-u_{k}^{*}\right)}+1-A^{*}-\left(1-m_{i}\right) \theta_{i}\left(1-w_{i}^{*}\right)\right] i^{*}} \\
& {\left[\left(l-u_{k}^{*}\right)\right]\left(\pi^{*}-\delta^{*}\right)+z\left(\pi-\pi^{*}\right)}
\end{aligned}
$$

Source: Authors' calculations. 


\begin{tabular}{|c|c|c|c|}
\hline Real Rate of Return or Tax Wedge & Symbol & Derivation & Expression \\
\hline (1) Market return & $r^{*}$ & & $p^{*}-\pi^{*}$ \\
\hline (2) Discount rate investor & $r_{f}^{*}$ & & $\left(p^{*}-\pi^{*}\right)\left[1-\epsilon^{*}\left(u_{k}^{*}-u_{s}^{*}\right)\right]$ \\
\hline (3) Cost of capital & $p^{*}$ & & $\frac{\left(1-A^{*}\right)}{\left(1-u_{k}^{*}\right)}\left(\rho^{*}-\pi^{*}\right)\left[1-\epsilon^{*}\left(u_{k}^{*}-u_{s}^{*}\right)\right]+\delta^{*}-\delta^{*}$ \\
\hline (4) Effective subsidy on capital goods & $A^{*}$ & & $f_{1}^{*} u_{d}^{*} A_{d}^{*}+f_{2}^{*} u_{d}^{*}+f_{3 g^{*}}^{*}$ \\
\hline (5) Corporate tax wedge & $t_{c}^{*}$ & $(3)-(1)$ & {$\left[\frac{u_{k}^{*}-A^{*}}{\left(1-u_{k}^{*}\right)}\right]\left(\rho^{*}+\delta^{*}-\pi^{*}\right)-\epsilon^{*}\left(u_{k}^{*}-u_{s}^{*}\right) \frac{\left(1-A^{*}\right)}{\left(1-u_{k}^{*}\right)}\left(p^{*}-\pi^{*}\right)$} \\
\hline (6) Return after withholding tax & $r_{w}^{*}$ & & $\left(1-\epsilon^{*} w_{d}^{*}\right)\left(\rho^{*}-\pi^{*}\right)$ \\
\hline (7) Withholding tax wedge & $t_{w}^{*}$ & $(1)-(6)$ & $\epsilon^{*} w_{d}^{*}\left(\rho^{*}-\pi^{*}\right)$ \\
\hline (8) Host tax wedge & $t_{H}^{*}$ & $(3)-(6)=(5)+(7)$ & $\begin{aligned} \epsilon^{*} w_{d}^{*}\left(\rho^{*}-\pi^{*}\right)+\left[\frac{u_{k}^{*}-A^{*}}{\left(1-u_{k}^{*}\right)}\right]\left(\rho^{*}+\delta^{*}-\pi^{*}\right) \\
-\epsilon^{*}\left(u_{k}^{*}-u_{s}^{*}\right) \frac{\left(1-A^{*}\right)}{\left(1-u_{k}^{*}\right)}\left(\rho^{*}-\pi^{*}\right)\end{aligned}$ \\
\hline (9) Return after tax & $s$ & & {$\left[\epsilon^{*}\left(1-m_{d}\right) \theta_{d}\left(1-w_{d}^{*}\right)+\left(1-\epsilon^{*}\right)(1-c)\right]\left(\rho^{*}-\pi^{*}\right)-\left[(c-z) \pi^{*}+z \pi\right]$} \\
\hline (10) Residence tax wedge & $t_{R}$ & $(6)-(9)$ & {$\left[\epsilon^{*}\left(1-w_{d}^{*}\right)\left[1-\left(1-m_{d}\right) \theta_{d}\right]+\left(1-\epsilon^{*}\right) c\right]\left(\rho^{*}-\pi^{*}\right)+(c-z) \pi^{*}+z \pi$} \\
\hline (11) Personal tax wedge & $t_{p}$ & $(1)-(9)=(7)+(10)$ & {$\left[\epsilon^{*}\left[1-\left(1-m_{d}\right) \theta_{d}\left(1-w_{d}^{*}\right)\right]+\left(1-\epsilon^{*}\right) c\right]\left(\rho^{*}-\pi^{*}\right)+(c-2) \pi^{*}+z \pi$} \\
\hline \multirow[t]{3}{*}{ (12) Total tax wedge } & $\mathrm{t}$ & $\begin{array}{l}(3)-(9)=(8)+(10) \\
=(5)+(11)\end{array}$ & $\left(\frac{\epsilon^{*}\left(1-A^{*}\right)\left[1-\left(u_{k}^{*}-u_{s}^{*}\right)\right]-\left(1-m_{d}\right) \theta_{d}\left(1-w_{d}^{*}\right)\left(1-u_{k}^{*}\right)}{\left(1-u_{k}^{*}\right)}\right)\left(\rho^{*}-\pi^{*}\right)$ \\
\hline & & & $+\left\{\frac{\left(1-\epsilon^{*}\right)\left[1-A^{*}-(1-c)\left(1-u_{k}^{*}\right)\right]}{\left(1-u_{k}^{*}\right)}\right\}\left(\rho^{*}-\pi^{*}\right)$ \\
\hline & & & $+\left[\frac{u_{k}^{*}-A^{*}}{\left(1-u_{k}^{*}\right)}\right] \delta^{*}+\left[(c-z) \pi^{*}+z \pi\right]$ \\
\hline
\end{tabular}

Source: Authors' calculations. 
Table 8A.3 Definition of Parameters

Description

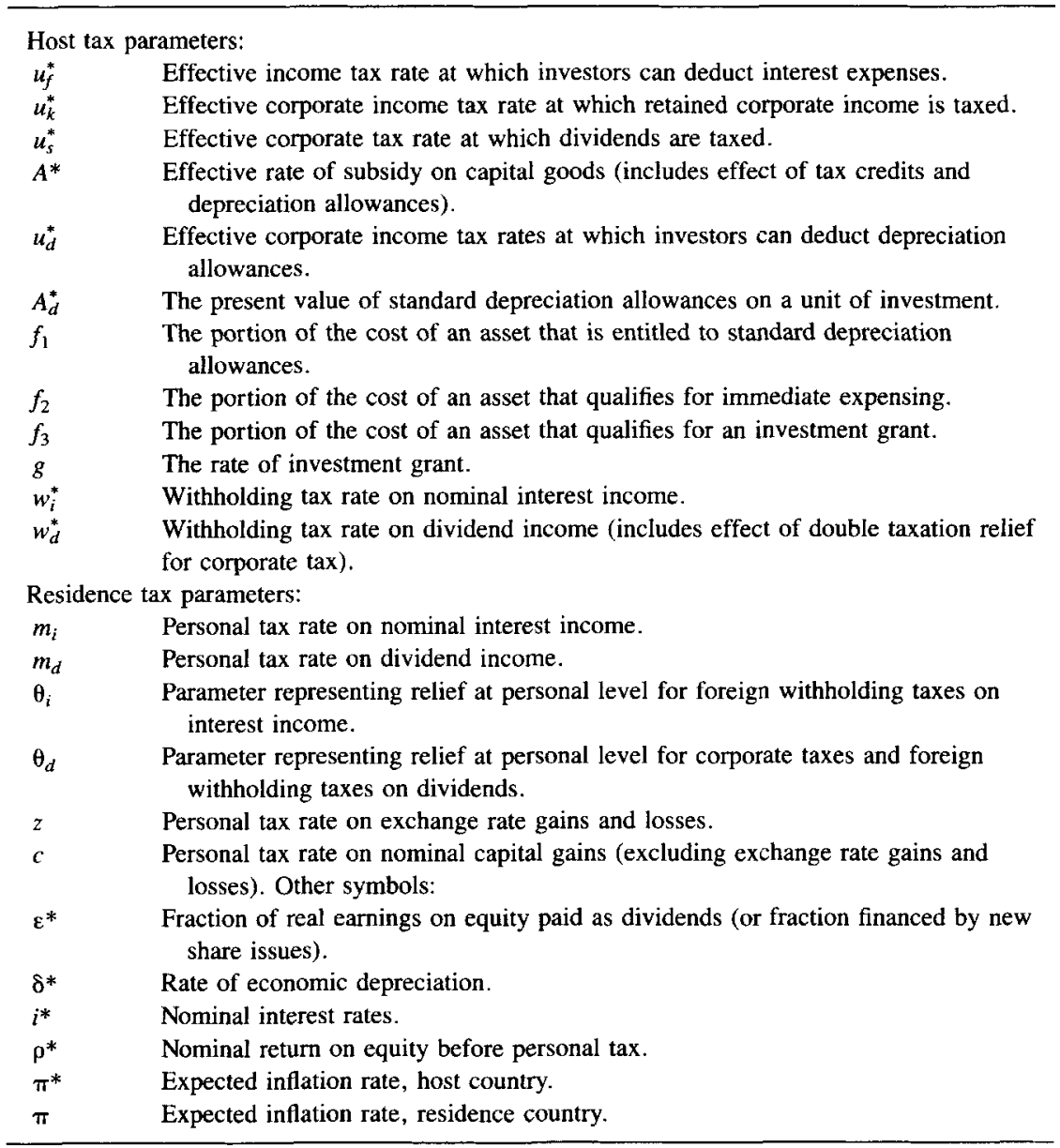

Source: Authors' calculations.

\section{Notes}

1. Auerbach (1983) and Boadway (1985) provide excellent surveys of the literature in this area.

2. Alternatively, the effective marginal tax rate, found by dividing the tax wedge by the before-tax rate of return $p$, can describe the effects of capital income taxation. 
3. Thus, the investment demand curve is in flow terms rather than in stock terms because this section focuses on the short-term equilibrium. These flow demands are derived from a model with adjustment costs, which prevent instantaneous stock adjustment. Alternatively, one could model the long-term capital market equilibrium in stock terms. In that case, a lower $p$ would raise the stock demand for capital. This would imply a higher rate of net investment during the transition, assuming rising short-run adjustment costs.

4. Results below indicate that in some cases the tax wedge is negative. In that case, the government subsidizes marginal investments.

5 . Thus, the social costs of postponing consumption equal the private costs. This assumes that private saving does not generate any externalities, which requires that the government can attain the first-best growth path by transferring income between generations in a lump-sum fashion.

6. This assumes that the government can use nondistortionary taxes, such as a lump-sum tax. Otherwise, the social value of one marginal unit of tax revenue may exceed unity.

7. This assumes that assets are perfect substitutes. Moreover, corporate taxes are assumed to be levied on a source basis, while the residence principle governs personal taxation. Subsection 8.3.2 explains and elaborates on these assumptions and relaxes some of them.

8. Over time, the current account deficit may fall as the investment and savings schedules shift in response to the accumulation of capital and wealth.

9. This assumes that the host country collects all corporate taxes, while the residence country collects all personal taxes. Accordingly, withholding taxes on personal income are assumed to be zero. Subsection 8.3.6 discusses and relaxes some of these assumptions.

10. Only if tax wedges do not affect the market return in a closed economy would the welfare costs in a closed economy equal those in an open economy. In all other cases, the welfare costs in an open economy exceed those costs in a closed economy.

11. If savings are elastic with respect to the after-tax rate of return, capital income taxation affects the global capital stock and, therefore, global intertemporal efficiency. In the absence of externalities, the total tax wedges measure the gap between the social benefits of a marginal investment and the social costs of financing it by a marginal unit of saving (see subsec. 8.2.2). Accordingly, they provide information on how marginal changes in the world capital stock affect global welfare.

12. Under a territorial system, the residence country exempts foreign-source income from corporate taxation. Under a system of worldwide taxation, the residence country taxes global income but credits foreign corporate taxes against domestic corporate tax liabilities as long as foreign corporate taxes do not exceed the domestic corporate tax liabilities calculated on the foreign-source income.

13. Differential opportunities for tax evasion are a fourth reason why the residence principle may fail. Savers may find it easier to evade residence taxes on foreign assets than corresponding taxes on domestic assets.

14. Another important case is savings channeled through banks because withholding taxes are imposed on gross interest income so that no deduction is allowed for interest expense and other costs of making the loan. The withholding taxes, therefore, often exceed the residence tax liability on net income from bank loans.

15. Accordingly, this study does not assume that savers necessarily require the same after-tax rate of return $s$ on assets located in different countries. Thus, $s_{A}^{A}$ is not necessarily equal to $s_{A}^{B}$ in fig. 8.7. 
16. Tax wedges provide an unambiguous indicator of the effect of the tax system on investment incentives only if the tax wedge on assets located in country A exceeds that on assets located in B for all savers, i.e., both those residing in A and those in B.

17. This discussion of national welfare effects abstracts from optimal tariff type arguments by assuming that countries lack market power to affect the cost of funds on world markets. For an application of such arguments to international capital taxation, see Sinn (1987, chap. 7) and Gordon and Varian (1987). Furthermore, the study does not deal with strategic considerations, which would become relevant if the tax system in one country were perceived to affect tax policy in another country.

18. For a marginal investment financed by domestic savings, the total tax wedge represents the gap between national benefits and costs. For the assumptions underlying this approach, see subsec. 8.2.2 and, in particular, the notes in that subsection. It is assumed, for example, that the government can raise revenue through nondistortionary taxes.

19. This paper assumes that firms do not finance their investments with foreign currency bonds.

20. Projects located in the same country are assumed to pay both a unique nominal interest rate on debt and a unique nominal after-corporate-tax return on equity.

21. Thus, perfect foresight is assumed. The inflation rates in 1988 and 1989 are taken from the projections contained in the World Economic Outlook of April 1988.

22. Tax wedges were calculated by using observed rather than uniform nontax parameters in order to capture the interaction between tax provisions and the macroeconomic environment. However, to examine the sensitivity of the results to the values of nominal interest and inflation rates, we also computed tax wedges assuming a constant nominal interest rate of 8 percent and a constant expected inflation rate of 4 percent across countries and over time. The sensitivity analysis revealed that the development of the relative tax wedges was very similar to the results presented in this paper.

23. This construction typically opens up arbitrage opportunities at the savers (or household) level and requires imperfect substitution at the household level between debt and equity.

24. According to the estimates in Hatsopoulos and Brooks (1987) and Ando and Auerbach (1987), the gap between the cost of equity and debt financing was larger in the United States. The current study assumes that the gap is the same in the United States and Japan in order to identify how international differences in tax factors, as opposed to differences in the structure of financial intermediation, affect investment incentives.

25. Some studies allow for an exogenous risk premium on equity. See, e.g., Feldstein (1986). Others measure the return on equity directly by using the inverse of the observed price-earnings ratio on shares. See, e.g., Boadway, Bruce, and Mintz (1987).

26. Even in a closed economy, the tax burden on debt relative to equity can differ among individuals with different marginal tax rates. Moreover, imposing arbitrage conditions on the savers' side is problematic even in a closed economy because it generally implies that a given piece of capital earns a different before-tax rate of return depending on how it is financed (see, e.g., Bradford and Stuart 1984). Therefore, the firm can typically obtain arbitrage profits by specializing in the least expensive type of financing.

Alternatively, one can use the arbitrage condition for only one particular saver. Sinn (1987), e.g., imposes the arbitrage condition only for savers in the host country because he assumes that debt accounts for all international portfolio capital flows and that all equity is held domestically. As an alternative procedure, Alworth and Fritz (1988) average the arbitrage conditions for all savers to arrive at one "world" arbitrage condition. 
27. Interest income from small deposits (Maru-yu accounts) with banks and other financial institutions was tax exempt if the total amount of principal did not exceed $¥ 3$ million. Tax-exempt savings included holdings of central and local government bonds, not exceeding $¥ 3$ million in total face value (special "Maru-yu"), postal savings not exceeding $¥ 3$ million, and savings under the Employees’ Asset Formation System not exceeding $¥ 5$ million. Those tax-exempt savings accounted for about 70 percent of the total balance of personal savings. From April 1988, the tax-exempt systems for Maru-yu, special Maru-yu, and postal savings were abolished, and earnings on these savings are now subject to a 20 percent final tax at source.

28. Thus, if savers channel the funds through a financial intermediary, the intermediary is assumed to have sufficient tax liabilities against which to credit withholding taxes.

29. This effect of inflation dominates the negative effect of inflation on the present value of depreciation allowances.

30. The negative numbers in the third row of the first panel in table 8.8 reveal this. The relatively favorable personal tax treatment of assets located in Japan implies that relative corporate tax wedges overestimated the tax incentives for investment in assets located in the United States.

31. If assets are not close substitutes in portfolios and savers residing in different countries have different preferences for assets, this result may no longer hold. To illustrate, if savers prefer assets located domestically, the higher corporate tax burden on assets located in Japan may have offset the positive incentive effects of the favorable personal tax treatment of Japanese savers. In fact, for both equity and debt financing, the Japanese government taxed locally financed Japanese assets more heavily than the U.S. government taxed local assets. Thus, in the extreme case of savers holding only domestic assets, which is equivalent to a closed economy without any international capital flows, Japanese savers were taxed more heavily than U.S. savers. This result illustrates the important role of more open international capital markets in changing the tax incentives for savings and investment behavior. For an analysis within a closed economy, see Shoven and Tachibanaki (1985) and Makin and Shoven (1987).

32. Following the period of analysis, Japan raised its tax rate on interest income in 1988.

33. In principle, computing the effective tax rate requires expected rather than actual tax parameters. This study, however, uses actual tax provisions to approximate the anticipated provisions.

34. If a saver finances an investment located in his or her own country, the residence and host countries coincide.

35. It is assumed that corporate taxes are not credited in the residence country (see subsec. 8.3.1).

36. The corporate tax wedge does not depend on whether the investment is financed by domestic or foreign savers. In Sinn (1987), the corporate tax wedge depends on the tax treatment of interest and equity income at the personal level in the host country. This is because Sinn (1987) assumes that domestic equity finances a fixed part of domestic investment and that domestic households earn the same after-tax return on equity and debt.

37. For a critical evaluation of this approach, see subsec. 8.3.2.

38. The expressions in table 8A.2 assume that the real return on new share issues is paid in dividends. The purely nominal inflationary gain is reflected in capital gains. This is similar to the procedure in Feldstein (1986) and Boadway, Bruce, and Mintz (1987) but different from that in King and Fullerton (1984). 
Sinn (1987) argues, along the lines of the "new" view of dividend taxation, that investors generally adopt profit retentions rather than new share issues as the marginal source of equity finance. In that case, dividend taxes, including withholding taxes on dividends, fail to distort investment decisions and amount to a lump-sum tax on existing rather than a tax on new capital. Dividend taxes affect new investment only when dividends are not paid; in that case, internal investment absorbs all profits, and investors are forced to generate new equity capital through new share issues. Hartman (1985) uses similar arguments to argue that home taxation of direct investment is largely irrelevant for direct investment decisions in the presence of deferral provisions.

39. The tax rate on exchange rate gains is generally lower than the tax rate on interest income because it is the rate on accrued gains and losses rather than the statutory rate on realized gains. Moreover, countries often set the tax rate on capital gains, including exchange rate gains, at a rather low level in order to encourage investors to trade their assets and realize their capital gains so as to avoid large efficiency losses and, in some cases, revenue loses.

40. The paper assumes that savers expect nominal exchange rates to adjust fully for the effects of intercountry differences in expected inflation rates. See also Boadway, Bruce, and Mintz (1984) and Gordon (1986).

\section{References}

Alworth, Julian S., and Wilhelm Fritz. 1988. Capital mobility, the cost of capital under certainty and effective tax rates in Europe. Finnish Economic Papers 1: $25-44$

Ando, A., and A. J. Auerbach. 1987. The cost of capital in the U.S. and Japan: A comparison. NBER Working Paper no. 2286. Cambridge, Mass.: National Bureau of Economic Research.

Auerbach, Alan J. 1983. Taxation, corporate financial policy, and the cost of capital. Journal of Economic Literature 21; 905-40.

Bernheim, Douglas, and John B. Shoven. 1987. Taxation and the cost of capital: An international comparison. In The consumption tax: A better alternative? ed. Charles E. Walker and Mark A. Bloomfield. Cambridge, Mass.: Ballinger.

Boadway, Robin M. 1985. The theory and measurement of effective tax rates. In The impact of taxation on business activity, ed. J. M. Mintz and D. Purvis. Kingston, On.: John Deutsch Institute for the Study of Economic Policy, Queens University.

Boadway, Robin M., Neil Bruce, and Jack M. Mintz. 1984. Taxation, inflation, and the effective marginal tax rate in Canada. Canadian Journal of Economics 17: $62-79$.

1987. Taxes on capital income in Canada: Analysis and policy. Canadian Tax Paper, no. 80. Toronto: Canadian Tax Foundation.

Bradford, David, and Charles Stuart. 1984. Issues in the measurement and interpretation of effective tax rates. National Tax Journal 39: 307-16.

Brean, Donald J. S. 1984. International issues in taxation: The Canadian perspective. Canadian Tax Paper, no. 75.

Corker, R. J., O. Evans, and L. Kenward. 1988. Tax policy and business investment in the United States: Evidence from the 1980s. International Monetary Fund. Typescript. 
Feldstein, Martin. 1986. Budget deficits, tax rules, and real interest rates. NBER Working Paper no. 1970. Cambridge, Mass.: National Bureau of Economic Research.

Fukao, Mitsuhiro, and Masaharu Hanazaki. 1987. Internationalisation of financial markets and the allocation of capital. OECD Economic Studies (Paris), no. 8, $35-92$.

Fukao, Mitsuhiro, and K. Okima. 1988. Balance of payments imbalances and long-term capital movements: Review and prospects. Bank of Japan Research Paper, March.

Fullerton, A. D., and M. Karayannis. 1987. The taxation of income from capital in the United States, 1980-86. NBER Working Paper no. 2478. Cambridge, Mass.: National Bureau of Economic Research.

Gordon, Roger H. 1986. Taxation of investment and savings in a world economy. American Economic Review 76 (5): 1086-1102.

Gordon, Roger H., and Hal R. Varian. 1987. Taxation of asset income in the presence of a world securities market. University of Michigan. Mimeo.

Hartman, David G. 1985. Tax policy and foreign direct investment. Journal of Public Economics 26 (1): 107-21.

Hatsopoulos, B. G., and S. H. Brooks. 1987. The cost of capital in the United States and Japan. Paper presented to the International Conference on the Cost of Capital, Harvard University.

Kikutani, F., and T. Tachibanaki. 1987. The taxation of income from capital in Japan: Historical perspectives and policy implications. Paper presented to the International Conference on the Cost of Capital, Harvard University.

King, M., and A. D. Fullerton. 1984. The taxation of income from capital: A comparative study of the United States, the United Kingdom, Sweden, and West Germany. Chicago: University of Chicago Press.

Makin, John H., and John B. Shoven. 1987. Are there lessons for the United States in the Japanese tax system? In Contemporary economic problems: Deficits, taxes, and economic adjustments, ed. Phillip Cagan. Washington, D.C.: American Enterprise Institute.

Sato, Mitsuo, and Richard Bird. 1975. International aspects of the taxation of corporations and shareholders. Staff Papers (International Monetary Fund, Washington, D.C.) 22: 384-455.

Shoven, John B., and T. Tachibanaki. 1985. The taxation of income from capital in Japan. Stanford University. Mimeo.

Sinn, Hans-Werner. 1987. Capital income taxation and resource allocation. Amsterdam: North-Holland.

Sorenson, Peter B. 1986. Taxation, inflation, and asset accumulation in a small open economy. European Economic Review 30: 1025-41.

Sorenson, Peter B. 1987. Reforms of Danish capital income taxation in the 1980s. Paper presented to the Conference on the cost of Capital, Harvard University.

Tachibanaki, Toshiaki. 1988. Government policies, the working of financial markets, saving and investment in Japan. Discussion paper no. 252. Kyoto: Kyoto Institute of Economic Research.

Tanzi, Vito. 1988. Income taxes, interest rate parity, and the allocation of international savings in industrial countries. In Tax policy and economy, ed. Antonio Pistone. Padova: Cedam.

Tanzi, Vito, and A. Lans Bovenberg. 1988. Economic interdependence and the international implications of supply-side policies. In A supply-side agenda for Germany: Stimulation from the United States and Great Britain, ed. G. Fels and G. Von Furtsenberg. Heidelberg and New York: Springer. 


\section{Comment Alan J. Auerbach}

This paper represents a first attempt to introduce an important element of international taxation to the international tax comparison "industry." In the past, authors have followed the lead of King and Fullerton (1984) in calculating the marginal tax rates for domestically financed business investment for different countries and then comparing these results across countries. Absent international capital flows, such comparisons would tell us about the relative tax distortions confronting capital formation and saving in each country, with the savinginvestment identity making further distinctions meaningless.

However, such flows are not absent. If domestic saving and investment can move independently (they can, though the controversy continues about how much they do), what do these overall wedges tell us? Not necessarily very much. For example, a large wedge in the United States could primarily discourage domestic investment or domestic saving, depending on how the tax was assessed. The incidence and efficiency effects would turn on this question, as would the direction of induced capital flows. Indeed, if marginal funds for U.S. investment come from Japan, for example, then the "right" overall wedge for U.S. capital formation is the one that combines the investment wedge at home with the saving wedge in Japan. Even that approach is too simple, however, because one cannot generally distinguish separate saving and investment wedges. Japanese savers face different rates of tax on foreign and domestic assets, so we must look at each individual saving-investment country combination to obtain a complete description of the relevant tax incentives.

This is what the paper does admirably well, for a particular class of investments. It leaves open the question of the equilibrium that these distortions generate and the extent to which they are even compatible with capital market equilibrium in the absence of imperfect capital flows or asset substitutability. In considering only portfolio investment, it produces the most straightforward extension of the previous closed economy analysis but leaves aside the empirically more significant and conceptually more complex categories of foreign direct investment and investment by financial intermediaries. We learn from table 8.2 that such portfolio investment represented 20 percent of U.S. investment abroad during the period 1980-87 and 31 percent of foreign investment in the United States. Further whittling down these numbers to account for the fact that only one type of ultimate capital purchase, machinery and equipment, is considered, one finds that this paper's calculations apply to roughly 20 percent of foreign private investment in the United States during the period 1980-87 and, if one

Alan J. Auerbach is professor of economics at the University of Pennsylvania and a research associate of the National Bureau of Economic Research. 
assumes the same investment breakdown elsewhere, 13 percent of U.S. private investment abroad.

While the authors do make certain conjectures about how other assets and forms of investment might be affected, one must be fairly cautious in drawing, one might say, global inferences based on the paper's results. Still, there is much of interest here. Before performing their tax wedge calculations, Bovenberg et al. must confront several methodological issues, most of which also arose in the original King-Fullerton international comparisons. These questions do not have simple answers, but little space is devoted to the choices made, even when they diverge from previous approaches. This is primarily a relatively painful collection of index-number problems the details of which the reader might be grateful to be spared, but a brief discussion is worthwhile.

The key problem is how to determine the rate of return to use as a base for each calculation. This leads to problems within each country and problems in comparing the two countries.

Unless a tax system taxes true economic income, the effective tax rate will depend on the rate of return assumed, either before tax or after tax. Even when the effective tax rate is invariant with respect to the assumed rate of return, the tax wedge (i.e., the numerator of the effective tax rate calculation) will almost surely increase with the assumed rate of return since part of the tax wedge is associated with the tax rate applied to gross cash flows. Thus, the choice of rate of return influences the estimated tax wedge. One cannot assume that all rates of return, before tax and after tax, are equal, of course, but one can assume that all before-tax rates are equal, all after-tax rates are equal, or all real interest rates are equal, corresponding to the King-Fullerton fixed- $p$, fixed- $s$, and fixed-r cases. In my view, any of these would be preferable to the use of observed rates of return in the United States and Japan. Under the current methodology, it would be possible for the two countries to have identical tax systems and even identical inflation experience and yet have systematic tax wedge differences owing to real interest rate differentials. Surely one would not wish to base conclusions about tax policy differences on such results.

Likewise, I do not see the merit in assuming a differential rate of return between debt and equity. It is true that the after-tax return of equity exceeds that of debt, but this is due to risk, a factor not considered in this paper or, to be fair, in most previous efforts either. As has been developed in the literature on risky asset taxation (Auerbach 1983; Bulow and Summers 1984; Gordon and Wilson 1989), one cannot treat an asset with a high expected risky return like one with a high safe return when calculating the asset's tax burden. If assets are to be assumed free of risk, one might as well ignore the risk premia that they actually carry.

A final comment in this vein is that, if one uses ARIMA forecasts of the inflation rate for Japan, consistency would dictate doing so for the United States, even if conceivably better forecasts are available. 
Let me turn now to the empirical calculations that are the paper's primary contribution. There are many parameter assumptions necessary to perform these calculations. While one can quarrel with particular choices, I do not see anything unreasonable in them. The results indicate that Japan has taxed investment more heavily and saving less heavily than the United States, a result not unexpected given the previous closed economy calculations of corporate and investor tax wedges reported by Shoven and Tachibanaki (1988). We also learn, from the last three columns of table 8.8, that the lack of formal separability of savings-tax and investment-tax wedges is relatively unimportant: the gap between total tax wedges faced by U.S. and Japanese savers depends very little on where they are assumed to be investing. This could be the result of complete foreign tax crediting but seems here to be due more directly to the unimportance of host country taxes on investor income. It is hard to tell whether this result would also hold for the more complicated ownership patterns excluded from consideration in the paper.

We learn from the last three columns of tables 8.6 and 8.7 that the relative tax advantage of savers in Japan has declined over the past decade and from the first six columns of table 8.8 that the relative tax advantage of investment in the United States rose in the early 1980s and fell in the late 1980s, presumably as the result of the important tax acts of 1981 and 1986. These results suggest that the saving-investment imbalance that has characterized the two countries' bilateral relations may in part have been due to tax policies and that recent policy changes ought to have lessened these imbalances. But, to go further in macroeconomic and welfare analysis, we need not only prices but quantities.

Here, the paper becomes less specific, talking generally about the theoretical welfare and macroeconomic effects but not using the empirical estimates to apply the theory. One could extend the theory a little bit further, by noting, for example, that the deadweight cost due to the distortion of international capital allocation when saving is not fixed would be approximately $-1 / 2 \sum_{i, j}\left(p_{i}-s_{i j}\right) K_{i j}$, where $K_{i, j}$ is the capital of type $i$ held by savers of type $j$, and that the relevant saving elasticity would be a compensated one that would always be positive. It would also be useful to flesh out the conditions under which international asset specialization would occur.

But to do much more welfare analysis than this, one would need a more explicit model of international capital flows, one that would account for the imperfect substitutability that seems present in these asset markets and the more complicated tax rules that apply to foreign direct investment and financial intermediaries. This paper has brought us well beyond the closed economy effective tax rate calculations of the past but shares with previous efforts a focus on the level and dispersion of relative tax rates rather than on the fuller story including a characterization of the associated quantity adjustments and their welfare and macroeconomic consequences. This is not to deny the progress that the authors have made, only to point out the next 
important step in this line of research. This next step is perhaps even more important in the open economy context; with several alternative ownership structures available for any given underlying real transaction, tax rate dispersion need not be a good indicator of the extent to which capital allocation is distorted, and "representative" overall effective tax rates are hard to come by.

\section{References}

Auerbach, Alan J. 1983. Corporate taxation in the United States. Brookings Papers on Economic Activity 2:451-505.

Bulow, Jeremy I., and Lawrence H. Summers, 1984. The taxation of risky assets. Journal of Political Economy (February), 20-34.

Gordon, Roger H., and John D. Wilson. 1989. Measuring the efficiency cost of taxing risky capital income. American Economic Review (June), 427-39.

King, Mervyn, and Don Fullerton, eds. 1984. The taxation of income from capital. Chicago: University of Chicago Press.

Shoven, John B., and Toshiaki Tachibanaki. 1988. The taxation of income from capital in Japan. In Government policy towards industry in the United States and Japan, ed. John B. Shoven. Cambridge: Cambridge University Press 